Review

\title{
Small Extracellular Vesicles: Functions and Potential Clinical Applications as Cancer Biomarkers
}

\author{
Yi Wang ${ }^{1,2,+} \oplus$, Ruichen Zhao ${ }^{1,2,+}\left(\right.$, Xueqiao Jiao ${ }^{1,2,+} \oplus$, Longyuan $W u^{1,2}\left(\right.$, Yuxuan Wei ${ }^{1,2}$, Fuxiu Shi ${ }^{1,2} \mathbb{D}^{\text {, }}$ \\ Junpei Zhong ${ }^{1,2}$ and Lixia Xiong ${ }^{1,2, *(\mathbb{D})}$ \\ 1 Department of Pathophysiology, Medical College, Nanchang University, 461 Bayi Road, \\ Nanchang 330006, China; 401442719031@email.ncu.edu.cn (Y.W.); r.zhao@se17.qmul.ac.uk (R.Z.); \\ 6303416020@email.ncu.edu.cn (X.J.); 6300817039@email.ncu.edu.cn (L.W.); y.wei@se18.qmul.ac.uk (Y.W.); \\ 401428820001@email.ncu.edu.cn (F.S.); 401428820017@email.ncu.edu.cn (J.Z.) \\ 2 Jiangxi Province Key Laboratory of Tumor Pathogenesis and Molecular Pathology, 461 Bayi Road, \\ Nanchang 330006, China \\ * Correspondence: xionglixia@ncu.edu.cn; Tel.: +86-791-8636-0556 \\ + These authors contributed equally to this work.
}

Citation: Wang, Y.; Zhao, R.; Jiao, X.; Wu, L.; Wei, Y.; Shi, F.; Zhong, J.;

Xiong, L. Small Extracellular Vesicles: Functions and Potential Clinical Applications as Cancer Biomarkers. Life 2021, 11, 1044. https:/ / doi.org/ 10.3390/life11101044

Academic Editor: Prakash Gangadaran

Received: 27 August 2021 Accepted: 30 September 2021 Published: 4 October 2021

Publisher's Note: MDPI stays neutral with regard to jurisdictional claims in published maps and institutional affiliations.

Copyright: (c) 2021 by the authors. Licensee MDPI, Basel, Switzerland. This article is an open access article distributed under the terms and conditions of the Creative Commons Attribution (CC BY) license (https:// creativecommons.org/licenses/by/ $4.0 /)$.

\begin{abstract}
Cancer, as the second leading cause of death worldwide, is a major public health concern that imposes a heavy social and economic burden. Effective approaches for either diagnosis or therapy of most cancers are still lacking. Dynamic monitoring and personalized therapy are the main directions for cancer research. Cancer-derived extracellular vesicles (EVs) are potential disease biomarkers. Cancer EVs, including small EVs (sEVs), contain unique biomolecules (protein, nucleic acid, and lipids) at various stages of carcinogenesis. In this review, we discuss the biogenesis of sEVs, and their functions in cancer, revealing the potential applications of sEVs as cancer biomarkers.
\end{abstract}

Keywords: cancer; sEVs; liquid biopsy; clinical applications

\section{Introduction}

Cancer refers to a neoplasm characterized by abnormal and uncontrolled cell growth and high invasive capability. As the second leading cause of death worldwide [1], cancer is recognized as a serious public health problem that must be urgently addressed. Recently, many researchers have discovered evidence that cancer cell activities are largely dependent on extracellular vesicles (EVs), showing that EVs play a crucial role in the development of cancer, including the processes of angiogenesis, epithelial-to-mesenchymal transition (EMT), invasion, metastasis, immunosuppression, and drug resistance [2]. EVs are secreted to establish a favorable microenvironment for better growth through the transportation of various cargoes [3]. For example, cancer cells can domesticate their target cells by transporting RNA and DNA to influence their gene expression [4]. Cancer cells can also alter cell metabolism by sending specific proteins to cells of normal tissue [3].

Based on biogenetic mechanisms, EVs are divided into two major subtypes: plasma membrane-derived ectosomes (microvesicles/microparticles) and endosome-origin small extracellular vesicles (sEVs), with diameter varying from 30 to $100 \mathrm{~nm}$ or from 50 to $1000 \mathrm{~nm}$, respectively. A subset of ectosome are referred to as exosomes [5]. Ectosomes are also known as microvesicles, microparticles, or shedding vesicles [6,7]. Here, we use 'sEVs' to refer to EVs less than $200 \mathrm{~nm}$ in diameter. The size, and physical and chemical characteristics of EVs are detailed in Tables 1 and 2. 
Table 1. The size of extracellular vesicles.

\begin{tabular}{cccc}
\hline Vesicles & Size $\mathbf{( n m})$ & Origin & Reference \\
\hline Exosomes & $30-100$ & endosomes & {$[5]$} \\
Microvesicles & $100-1000$ & Plasma membrane & {$[8]$} \\
Apoptotic bodies & $500-2000$ & Plasma membrane, endoplasmic reticulum & {$[9]$} \\
\hline
\end{tabular}

Table 2. The chemical characteristics of extracellular vesicles [5].

\begin{tabular}{|c|c|c|}
\hline Characteristics & & Recommended Nomenclature \\
\hline Physical characteristics & $\begin{array}{l}\text { Size } \\
\text { Density }\end{array}$ & $\begin{array}{c}\text { Small: diameter }<200 \mathrm{~nm} \text { or }<100 \mathrm{~nm} \text {; Large and/or medium: }>200 \mathrm{~nm} \\
\text { Low; middle; high }\end{array}$ \\
\hline Biochemical composition & & e.g., $\mathrm{CD}^{+} 3^{+} / \mathrm{CD} 81^{+}$- EVs, Annexin A5-stained EVs, etc. \\
\hline Conditions or cell of origin & & e.g., podocyte EVs, hypoxic EVs, large oncosomes, apoptotic bodies, etc. \\
\hline
\end{tabular}

Due to their presence and stability in most body fluids [10,11], tumor-derived sEVs (TEVs) can be used as biomarkers for cancer detection, because the cargo they carry reflects genetic or signaling changes in the cancer cell of origin [12-14]. In addition, cancer cells secrete more sEVs than normal cells, which are released into the tumor microenvironment (TME) and circulation [2,15-19]. Furthermore, the contents of sEVs are potential biomarkers (such as microRNA(miRNAs)) which could improve the specificity of cancer diagnosis and prognosis [18,20-23], and help to manage and predict treatment responses. Therefore, further research into TEVs is needed. In this review, we summarize the processes involved in sEV biogenesis, the roles of sEVs in cancer functions, and their potential clinical applications as predictive biomarkers in various cancers.

\section{Biogenesis of sEVs}

Exosomes are a type of nanoscale, endogenously derived vesicle with phospholipid bilayers, and widely known as mediators of cell-to-cell communication by transferring cargo from one cell to another [24,25]. Exosome biogenesis begins with invagination of the endosomal-limiting membrane and the formation of intraluminal vesicles (ILVs). ILVs move toward the inside of the cell to load cargo, which can include DNA (mitochondrial, single-stranded, and double-stranded), RNA (messenger RNAs, miRNAs, and non-coding RNAs), or lipids, resulting in a specialized cell compartment, known as a multivesicular body (MVB). Extracellular release of ILVs is coordinated by the fusion of MVBs with the plasma membrane, resulting in the release of ILVs as exosomes [3,26] (Figure 1). Given their endosomal origin, exosomes are enriched in protein families involved in the construction of ILVs; for example, tetraspanins, tumor susceptibility gene 101(Tsg101), and ALG-2 interacting protein-X (Alix). Furthermore, exosomes carry non-specific proteins, such as membrane combination and transfer proteins (e.g., annexins, Rab, and flotillins), major histocompatibility complex (MHC) proteins (e.g., MHC I and MHC II), heat shock proteins (e.g., Hsp70 and Hsp90), and cytoskeleton proteins (e.g., myosin, actin and tubulin) [27].

The endosomal sorting complex (ESCRT) comprises four fundamental complexes, ESCRT-0, I, II, and III, and is the apparatus with foremost responsibility for conveying particular cargos into ILVs of MVBs, facilitating protein reuse [28]. In addition to the ESCRTdependent pathway, an ESCRT-independent route is also an available mechanism. For example, a few proteins, such as the Ras-related protein (Rab) family (Rab27a and Rab27b), four transmembrane-domain proteins (CD9, CD63, and CD81), and sphingomyelinase within the brain, also appear to be involved in lipid bi-layer formation, endosomal vesicle traffic, and vesicle release [29]. 


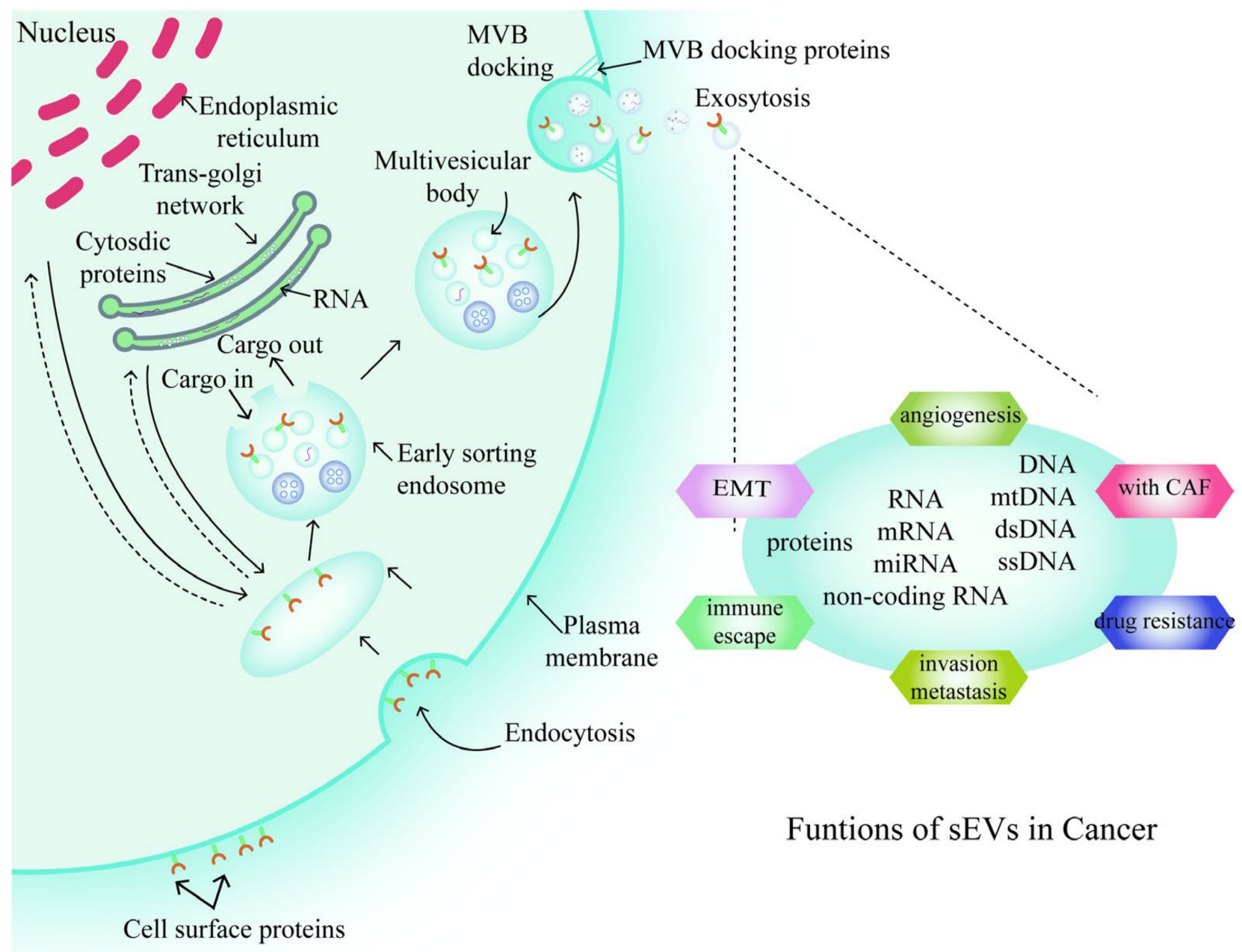

Figure 1. Steps in the formation of small extracellular vesicles (sEVs). Abbreviations: MVB, multivesicular body; EMT, epithelial-to-mesenchymal transition; CAF, cancer-associated fibroblast.

\section{Functions of sEVs in Cancer}

sEVs are among the most abundant carriers in nearly all body fluids, transporting different cargoes from an initial cell population to another, nearby or distant, and participating in various cell activities [3]. An increasing numbers of reports indicate that carcinoma-cell-derived sEVs transfer specific cargoes into recipient cells and modulate cancer processes; for example, angiogenesis, cell transformation, invasion, immune escape, and even drug resistance [30]. The specific roles of sEVs depend on their contents, including miRNAs, DNAs, tumor-derived proteins, and factors that modulate specific pathways [31]. The roles of sEVs in carcinogenesis can be categorized into six aspects, the role of sEVs in angiogenesis, epithelial-to-mesenchymal transition (EMT), invasion and metastasis, immune escape, cancer-associated fibroblasts (CAF), and drug resistance. As shown in Figure 2, sEVs derived from different cell populations can regulate different carcinogenic pathways via their distinct components [32]. We also explore the crucial roles of sEVs in drug resistance to probe the possibility for clinical application of sEVs against cancer recurrence and drug resistance [33]. 


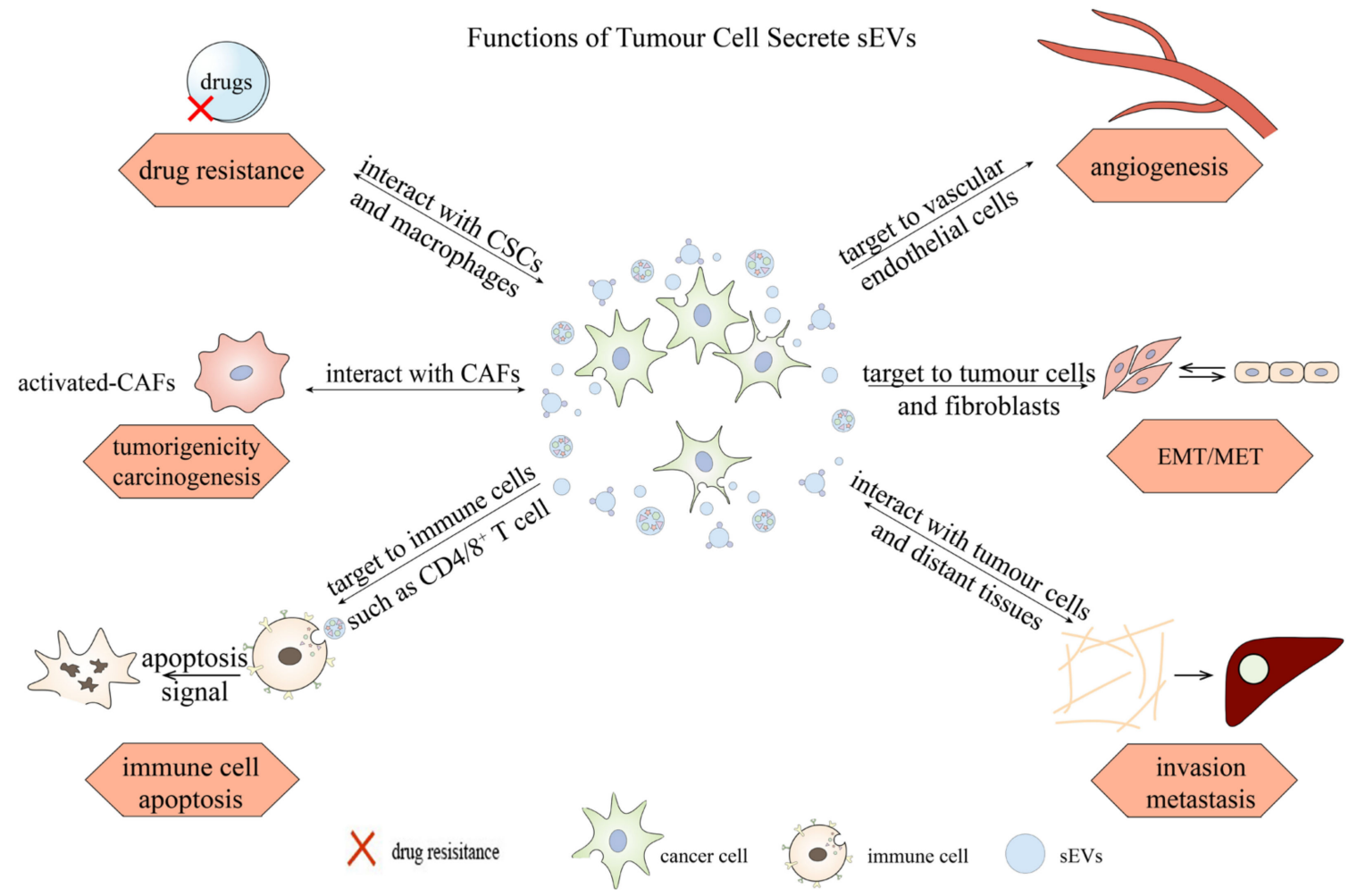

Figure 2. Six aspects of the roles sEVs in carcinogenesis. EMT/MET, epithelial-to-mesenchymal/mesenchymal-to-epithelial transition; sEVs, small extracellular vesicles; CAFs, cancer-associated fibroblasts; CSCs, cancer stem cells.

\subsection{The Role of $s E V$ s in Angiogenesis}

Angiogenesis, characterized as the arrangement of new blood vessels from a preexisting vascular system, occurs during tissue development and growth, as well as in reaction to harm, to reestablish the blood supply of a tissue and facilitate wound healing [34]. sEVs provide recipient cells with pro- and antiangiogenic factors, to remodel them for roles in angiogenesis and carcinogenesis [35]. The contents of sEVs differ, as various cancers have unique angiogenic mechanisms. For example, in glioblastoma, several proangiogenic molecules are found in TEVs, including angiogenin, fibroblast growth factor, vascular endothelia growth factor, interleukin-6 (IL-6), among others. These molecules promote angiogenesis and enhance the malignancy of spongioblastoma [36]. Another proangiogenic molecule, annexin II, derived from breast cancer cells, can promote tumor neo-angiogenesis [37]. sEVs in body fluid from patients with pancreatic adenocarcinoma and colon cancer are loaded with considerable amounts of tetraspanin 8 , which facilitates angiogenesis and metastasis [38,39]. Overall, angiogenesis relies on various proangiogenic or antiangiogenic molecules in sEVs, and sEVs are required for their transport from cancer cells to endothelial cells, and finally regulate the TME to enable tumor survival.

\subsection{The Role of sEVs in EMT}

The more aggressive malignant tumor cells become, the more likely they are to migrate to distant sites. To help facilitate this, a new metastatic niche is needed at the distant site, and tumor epithelial cells must go through the process of EMT [33]. In tumors, the local influence of sEV-mediated cell signaling can promote cancer cell aggression. These features include morphological changes, which are related to migratory functions (EMT, cytoskeletal reorganization, and aggressive pseudopodia formation), motility, and basement membrane remodeling activities. Serum sEVs containing miR-200 can affect the infiltration and colonization potential of cancer cells, indicating that TEVs are associated with an aggressive phenotype in cholangiocarcinoma [40]. It is conceivable that, epithelioid cancer cells and mesenchymal cancer cells can be identified based on the different substances carried by 
their sEVs, which could affect cancer metastasis or resistance to treatment [41]. Although TEVs can reshape distant, metastasis-prone organs (promoting metastasis [41,42]), the exact and comprehensive roles of sEVs in metastatic sites are not fully understood [43].

\subsection{The Role of sEVs in Invasion and Metastasis}

sEVs play an indispensable role in cancer development, invasion, and metastasis [44]. For example, in gastric cancer (GC), sEVs promote liver-specific metastasis by carrying and transferring epidermal growth factor receptors [45]. sEVs can also contribute to tumor metastasis by improving the tumor-cell-establishing premetastatic niche and remodeling the extracellular matrix. The premetastatic niche is a prerequisite for tumor metastasis, in which TEVs can advance tumor angiogenesis and thrombosis by stimulation of endothelial cells [46]. TEVs can also convert mesenchymal stem cells into myofibroblasts, to enhance tumor metastasis [47]; moreover, sEVs can induce both cell transformation and activation of specific signaling molecules during the process of metastasis, such as the proto-oncogene tyrosine-protein kinase, Src, focal adhesion kinase (FAK), and neurotrophic tyrosine kinase receptor type 1 (TrkA), in recipient cells [48,49].

\subsection{The Role of sEVs in Immune Escape}

TEVscan act as negative regulators of two molecules that function as $\mathrm{T}$ cell receptors, interleukin 2 receptor (IL-2R) and the T cell receptor, though inhibiting the expression and phosphorylation of Janus kinase (JAK) [50]. An intact JAK pathway is essential for the activity of cytokines, such as IL-2, IL-7, and IL-15, which share the gamma chain of IL-2R. Therefore, TEVs are detrimental to $\mathrm{T}$ cell proliferation and induce immune suppression by promoting regulatory $\mathrm{T}$ cell expansion and the demise of antitumor $\mathrm{CD} 8^{+}$effector $\mathrm{T}$ cells, thus contributing to tumor escape [50]. TEV-mediated signals lead to apoptosis of activated $\mathrm{CD}^{+} \mathrm{T}$ cells, which is related to cytochrome $\mathrm{C}$ discharge from mitochondria, early membrane changes in recipient cells, and DNA fragmentation [51]. TEVs target the $\mathrm{PI} 3 \mathrm{~K} / \mathrm{AKT}$ pathway in activated $\mathrm{CD}^{+} \mathrm{T}$ cells. When $\mathrm{CD}^{+} \mathrm{T}$ cells are regulated by TEV, AKT dephosphorylation decreases, as do expression levels of BCL-2, BCL-xL, and MCL-1, accompanied by increased levels of the pro-apoptotic protein, BAX [52]. In summary, TEVs have biological activity in tumor immune suppression, which negatively influences the functions of various immune cells by types via one or more molecular pathways that cause change in target cells.

\section{5. sEVs and Cancer-Associated Fibroblasts (CAFs)}

Cellular communications between cancer cells and surrounding stromal cells in the TME play important roles in regulating cancer progression and therapy responses [53]. Cancer-associated fibroblasts (CAFs) are crucial constituents of the TME that associate with cancer cells to advance tumorigenesis and movement [54], and sEVs can activate CAFs to influence the TME. In particular, prostate cancer cell-derived sEVs promote the activation of myofibroblasts [55]. TEVs also stimulate normal lung fibroblast activation (myofibroblast differentiation) in vitro [56] and advance the acquisition of myofibroblastlike characteristics in adipose tissue-derived mesenchymal stem cells [57]. These findings support that a role for TEVs in inducing CAF tumorigenicity. By contrast, CAF-derived sEVs can promote cancer progression by contributing to the chemoresistance of colorectal cancer (CRC) stem cells (CSCs) [58], and increasing the therapeutic resistance of breast cancer cells [59].

\subsection{The Role of sEVs in Drug Resistance}

With advances in pharmacology, anticarcinoma drugs have been rapidly developed and many patients now receive adequate treatment and have improved prognosis; however, drug resistance has emerged as a new problem. Like antibiological drugs, anticarcinoma drugs may have no effect in some cases, because of special mechanisms induced by tumor cells. Multidrug resistance proteins (MRPs) are key factors determining cancer drug 
resistance, which can also be affected by sEVs $[60,61]$. In one study, mesenchymal stem cell-derived sEVs were found to confer GC cell drug resistance both ex vivo and in vivo, mainly through their proteins, including multidrug resistance (MDR), MRP, and lung resistance-related protein [61]. In addition, the study showed that sEVs from doxorubicinresistant osteosarcoma cells are likely taken up into auxiliary cells, where they invoke a doxorubicin-resistant phenotype, and multidrug-resistant osteosarcoma cells are able to spread their capacity resist the impact of doxorubicin treatment by exchanging sEVs carrying MDR-1 mRNA and P-glycoprotein [60].

\subsubsection{Transfer of Drug Resistance Mediated by Cancer Stem Cell sEVs}

CSCs, a group of tumor cells in the TME with self-renewal and differentiation ability, are associated with drug resistance [62]. CSCs specifically express surface biomarkers, such as low levels of CD24 (CD24-/low) and high levels of CD44 (CD44 ${ }^{+}$, allowing their selection using simple techniques $[63,64]$. In addition to the strong correlation between CSCs and tumor expansion, metastasis, and relapse, several molecular mechanisms are mediated by CSC-derived sEVs, such as activation of CAFs and the induction of EMT [65-67]. CSCderived sEV miRNAs can contribute to the transfer of drug resistance to sensitive breast cancer cells. For example, miR-155 in CSC-derived sEVs may strengthen the resistance of breast cancer cells to paclitaxel and doxorubicin treatment [68]. Furthermore, the high level of miR-210 in pancreatic CSC sEVs from gemcitabine-resistant patients could transfer the resistant phenotype to gemcitabine-sensitive pancreatic cells [69].

\subsubsection{Macrophage Polarization and Drug Resistance}

In addition to inducing CSC activity, drug resistance can also be realized by activation of tumor-associated macrophages (TAMs). TAMs belong to the most plentiful group of immune cells in the TME and are involved in immunosuppression, tumor angiogenesis, and cell resistance to chemotherapy [70,71]. TAM populations in the TME are related to poor prognosis in various cancers, with a larger population often correlated with worse prognosis [72]. Furthermore, the sEV-mediated transfer of TAM-derived miR-21 can confer resistance to cisplatin, and targeting sEV-mediated communication may be a promising new therapeutic strategy for patients with GC [73]. In colon cancer, miR-1246 with in carcinoma-derived sEVs induce macrophages to acquire a TAM phenotype [74]. Similarly, other studies have shown that TEVs can enhance macrophage transition to TAMs via miRNAs in several types of cancer, including ovarian [75,76], bladder [77], and lung [78] cancer. In conclusion, TAMs are associated with drug resistance.

\section{4. sEVs as Biomarkers in Cancer}

TEVs are both potential biomarkers for monitoring cancer progression and potential targets for future treatments. Given that TEVs are detectable in all body fluids, including blood, urine, and bronchial fluids [79], they can function as biomarkers in liquid biopsies. Here, we discuss the clinical application of sEVs-derived proteins and nucleic acids as biomarkers. Due to the limited techniques, lipids or other biomolecules in sEVs are not available for detection to effectively transform research results into clinical application [80]. Moreover, TEVs can also be used as non-invasive biomarkers to manage treatment responses. Here, we will highlight examples of the potential for use of sEVs as cancer biomarkers in clinical practice and provide a vision for future clinical diagnosis and prognosis of cancer.

\section{1. sEVs Protein and Nucleic Acid Biomarkers}

\subsubsection{Nucleic Acids in sEVs}

miRNAs are RNA fragments of approximately 21-23 nucleotides that regulate gene expression in eukaryotic cells [81]. In cancer cells, miRNAs can also serve as biomarkers in cancer diagnosis. sEVs-derived miRNA can be detected for early cancer diagnosis, which may enhance both the sensitivity and specificity of tumor detection for lung cancer and 
pancreatic ductal adenocarcinoma (PDAC), for example [82,83]. In patients with hepatocellular carcinoma (HCC), researchers found that overexpression of sEV-derived miRNAs was associated with cancer diagnosis and prognosis [84]. The efficiency of different serum sEV-derived miRNAs for use in prognosis varies. For example, overexpression of serum exo-miR-215-5p is closely related to poor disease-free survival of patients with liver cancer, and can be used as a prognostic biomarker for HCC [85], however, the mechanisms underlying the activities of many miRNA remain unknown. Upregulation of circulating sEV-derived miRNA-373 [86], miRNA-1290, and miRNA-375 may have value for predicting prognosis of patients with prostate cancer [87].

Long-chain non-coding RNAs (lncRNAs) are a family of non-protein-coding RNAs (200 nt to $10 \mathrm{~kb}$ ) with distinct expression in various diseases, including malignant tumors [88]. LncRNAs have vital roles in regulating gene expression, alternative splicing mechanisms, protein localization and activity, as well as cell substructure and protein complex formation through various interactions with DNA, RNA, and proteins $[89,90]$. Several independent studies have demonstrated that sEV-derived lncRNAs are involved in the proliferation of various cancers [91], as well as chemoresistance [92] and stemness [93] qualities. It is reported that lncRNA actin filament associated protein 1 antisense RNA 1(AFAP1-AS1) confers trastuzumab resistance of breast cancer cells via packaging into sEVs. Mechanistically, AFAP1-AS1 promotes AUF1-mediated activation of ERBB2 translation, causing increased HER-2 expression and trastuzumab resistance [94]. Additionally, the lncRNA UFC1 (E2-like ubiquitin-fold modifier conjugating enzyme 1) expression level was increased in the serum sEVs of patients with non-small cell lung cancer (NSCLC). High levels of UFC1 were associated with tumor infiltration. Importantly, another study found that sEV-transmitted UFC1 could bind to EZH2 to downregulate PTEN gene expression and activate PI3K/Akt signaling, thereby promoting NSCLC tumorigenesis [95].

\subsubsection{Proteins in Cancer sEVs}

sEV proteins reflect their cellular origin and may help in cancer diagnosis. The intercellular transfer of oncoproteins by sEVs contributes to facilitating tumorigenesis $[96,97]$. sEV proteins are also useful in the dynamic monitoring of cancers. For example, compared with healthy control subjects or with PDAC who did not deteriorate after diagnosis and treatment, macrophage migration inhibitory factor is elevated in the circulating sEVs of patients with PDAC whose condition deteriorates [98]. Glypican-1(GPC-1) is a potential biomarker for pancreatic cancer diagnosis [99], and human leucine rich alpha-2-glycoprotein 1 (LRG1) in urinary sEVs is a potential biomarker for diagnosis of NSCLC [100].

\subsection{Potential of sEVs as Cancer Biomarkers \\ 4.2.1. Lung Cancer}

Lung cancer is one of the most dangerous cancers and efficient methods for its diagnosis are lacking. Liquid biopsy of sEVs is a method with high accuracy and specificity for early diagnosis of lung cancer [101], and sEV-derived miR-96 is a potential serum biomarker for malignant lung cancer [102]. In addition, the LIM-domain-only protein 7 (LMO7) gene is a target of miR-96. Targeting the miR-96-LMO7 axis could be used to develop new diagnostic or therapeutic strategies [103]. Studies also have been conducted to identify biomarkers from TEVs that can distinguish between adenocarcinoma (AC) and squamous cell carcinoma (SCC). The results showed that TEV miRNAs include the AC-specific molecules, miR-181-5p, miR-30a-3p, miR-30e-3p, and miR-361-5p; as well as the SCC-specific miR-10b-5p, miR-15b-5p, and miR-320b, which can be isolated from the plasma of patients with lung cancer. Expression levels of these sEVs miRNAs are reduced and can distinguish AC from SCC [104]. Further, sEV-mediated transmission of UFC1 expression was upregulated in tumor serum sEVs from patients with NSCLC and high level of UFC1 were associated with tumor infiltration [95], while LRG1 is expressed at higher levels in urinary sEVs from patients with NSCLC [100]. 


\subsubsection{Breast Cancer}

Breast cancer is a complex disease which is the second most common cause of cancerassociated death among women [105]. Therefore, it is fundamental to discover specific or sensitive biomarkers for early diagnosis and real-time monitoring of breast cancer. In one study, levels of miR-1246 and miR-21 were elevated in plasma sEVs from 921 patients with breast cancer compared with healthy patients [106], indicating that miR-1246 and miR-21 levels could potentially serve as a diagnostic biomarker for breast cancer. Furthermore, sEV-derived miR-1246 may inhibit Cyclin-G2 expression, thereby contributing to breast cancer progression. Thus, high levels of sEV-derived miR-1246 could be a prognostic biomarker for metastatic breast cancer [107]. One study revealed that the levels of sEVderived endothelial locus-1 (Del-1) were significantly up-regulated in patients with breast cancer relative to healthy people, and could be used as new diagnostic biomarker for patients with breast cancer [108].

\subsubsection{Prostate Cancer}

Prostate cancer is a malignant-epithelial tumor that usually appears in men over 50 years of age [109]. Currently, prostate cancer is most commonly clinically diagnosed by detecting the prostate-specific antigen (PSA); however, this method may miss some aggressive prostate cancers, and the diagnosis of prostate cancer requires new biomarkers [110]. One miRNA, miR-182, of the miR-183 cluster family, was detected in prostate cancer cell-derived sEV from serum [111], and miR-375 and miR-1290 have potential to predict the prognosis of castration-resistant prostate cancer [87]. A study investigating serum sEV miRNAs from patients with prostate cancer $(n=44)$ found that miR-1246 has potential to serve as a diagnostic marker, with a specificity of $100 \%$ and sensitivity of $75 \%$, for differentiating healthy individuals from those with prostate cancer [112].

\subsubsection{Colorectal Cancer (CRC)}

CRC is one of the most common malignant diseases globally and has a high mortality rate [113]. Consequently, screening and early detection of CRC are essential, and there is an urgent need to identify specific biomarkers for this cancer. CRC-cell-derived sEVs containing the lncRNA RPPH1 is up-regulated in plasma from patients with CRC and down-regulated after tumor resection [114]. Additionally, the expression of sEV-derived colorectal neoplasia differentially expressed-h (CRNDE-h) was increased in 148 patients with CRC [115]. In one sample set, seven miRNAs (let-7a, miR-1229, miR-1246, miR-150, miR-21, miR-223, and miR-23a) were significantly overexpressed in serum sEVs from patients with CRC [116]. Tetraspanin 1 (TSPAN1) is a cancer-related protein with a role in cell mitosis and leads to abnormal cell differentiation; TSPAN1 expression levels are significantly higher in patients with CRC than in healthy controls [117]. Hence, there is evidence that sEVs may be useful as effective diagnostic or prognostic tools in CRC.

\subsubsection{Gastric Cancer (GC)}

GC is the fourth most common malignant tumor globally and the most common cause of cancer-related death [118]. A recent study demonstrated that sEVs miRNAs are effective biomarkers in GC, where the up-regulation of miR-374a-5p in serum from patients with GC is an indicator of poor prognosis [119]. Furthermore, miR-217 overexpression enhances GC cell proliferation and reduces sEV CDH1 levels; hence, the imbalance of miR-217 in plasma sEVs can be used as a biomarker for GC diagnosis and classification [120]. Similarly, the sEV-derived lncRNA, undifferentiated-type early GC (UEGC), is remarkably up-regulated in patients with early GC, and can assist in early diagnosis of GC [121].

\subsubsection{Liver Cancer}

Liver cancer is classified into primary and metastatic types. HCC, the most common form of liver cancer, is a malignant tumor with high mortality rates [122]. Since liver cancer generally has no particular signs in its early stage, the optimal treatment period is often 
missed [123], as early diagnosis is imperative for effective HCC treatment. Clinical studies have demonstrated that serum sEV miR-9-3p levels in patients with HCC are significantly higher than those in healthy people; miR-9-3p can induce HCC cells by down-regulating the expression of fibroblast growth factor 5 (FGF-5), inhibiting ERK1/2-mediated proliferation, and repressing apoptosis [124]. Serum levels of miR-21 were higher in patients with HCC than those with chronic hepatitis B and healthy volunteers; however, the sensitivity of detection was much lower than that of sEV-derived miR-21. In addition, elevated serum sEV miR-21 levels were positively correlated with tumor stage in patients with HCC [125]. Furthermore, levels of the lncRNA HEIH were significantly higher in serum sEVs from patients with HCC than in those with chronic hepatitis $C$ and liver cirrhosis [126]. Moreover, levels of the lncRNA, activated by tumor growth factor- $\beta$ (lncRNA ATB), in serum sEVs from patients with HCC are also positively correlated with tumor TNM stage and volume [126]. Hence, there is potential for use of sEV components as tools for diagnosis or prognosis of liver cancer.

\subsubsection{Cervical Cancer}

Cervical cancer remains a leading cause of cancer-related deaths among women in developing countries [127]. Accurate and effective early screening methods are conducive to the prevention and early detection of cervical cancer, thereby improving patient survival rates [128]. In one study, 121 plasma samples from patients with cervical cancer and patients with precancerous signs were subjected to sEV miRNA sequencing, which demonstrated reduced expression of let-7d-3p and miR-30d-5p in patients with cervical cancer. Those sEV miRNAs may be useful for early detection of cervical cancer [129]. In addition, researchers collected cervicovaginal lavage specimens from patients with cervical cancer and found that expression levels of the lncRNAs, HOTAIR, MALAT1, and MEG3 differed significantly in cervical-TEVs relative to controls, and thus, may be useful for early detection and diagnosis [130].

\subsubsection{Bladder Cancer (BC)}

$\mathrm{BC}$ is the sixth most common malignant tumor in men and the seventeenth in women. Compared with healthy subjects, patients with BC have higher levels of sEVs in urine and serum samples. At different stages of disease, the sensitivity of TEVs in urine is higher than that of serum; however, serum is more specific and urine is more sensitive [131], which may be due to the high stability over time of sEVs, especially in the blood [132]. In one study, miR-21-5p, miR-141-3p, and miR-205-5p were detected as potential specific, non-invasive diagnostic tools for BC [133]. Similarly, the urine sEVs miRNAs, miR-19b1-5p, 136-3p, and 139-5p, are potential candidates for use in BC diagnosis [134].

\subsubsection{Diffuse Large B Cell Lymphoma}

Diffuse large B cell lymphoma (DLBCL) is an aggressive malignant lymphoma [135] and the standard prognostic assessment tool, the international prognostic index (IPI), can only anticipate survival time, not the impact of treatment [135]. However, analysis of the miRNA profiles of specific sEVs derived from DLBCL cells show that levels of sEV-derived miR-99a-5p and miR-125b-5p were significantly increased in the serum of patients with DLBCL [136]. In addition, circulating sEV-derived miR-451a is down-regulated in DLBCL compared with healthy controls $(P<0.0001)$ [137], while expression of miR-210, miR-155, and miR-21 is high in DLBCL serum [138]. These sEVs miRNAs may be new targets for diagnosis or treatment.

\subsubsection{Pancreatic Cancer}

Pancreatic cancer is the fourth leading cause of cancer deaths in the United States [1]. The high mortality rate is mainly due to late diagnosis and the aggressiveness of pancreatic cancer. At present, treatment options are limited $[139,140]$. Therefore, finding new strategies for early detection is key to improve the prognosis of patients with pancreatic can- 
cer, especially those with localized disease. Glypican-1+ circulating sEVs (GPC1+crExos) showed $100 \%$ sensitivity and specificity for each stage of pancreatic cancer (carcinoma in situ, stage I, and stage II-IV), and has the potential for use as a noninvasive diagnosis and screening tool to detect the early stages of pancreatic cancer and promote curative surgical treatment [141]. Furthermore, miR-196a and miR-1246 are highly selectively enriched in sEVs derived from pancreatic cancer cells, and can be used as biomarkers for different local pancreatic cancer subtypes [142].

\subsubsection{Endometrial Cancer}

Endometrial cancer (EC) is the sixth most common cancer among women worldwide [143], and most ECs are diagnosed early due to symptoms of postmenopausal uterine bleeding [144]. In one study that evaluated miRNA content in urine-derived sEVs miR-200c from isolated sEVs showed the largest fold-change value; hence, sEV-derived miR-200c may be useful as a preliminary diagnostic marker for EC [145]. In a meta-analysis of patients with EC, serum miR-21 was identified as a novel biomarker for EC, where higher serum miR-21 levels were detected in patients with benign lesions and EC than in healthy controls [146].

\section{5. sEVs and Future Perspectives in the Clinic}

As a subgroup of extracellular vesicles, sEVs play vital roles in intercellular communication and information transmission. Furthermore, sEVs from different origins regulate tumorigenesis via distinct mechanisms in almost all types of cancers. First, sEVs promote tumor angiogenesis and metastasis; $\mathrm{SEV}$ uptake up-regulates the expression of angiogenesis-related genes and enhances endothelial cell proliferation, migration, and growth [147]. Second, sEVs contribute to CAF transformation [148]. Third, sEVs can lead to the immune escape of tumor cells; the generation of an immunosuppressive environment is significant for cancer pathogenesis. Finally, sEVs protect cancer cells from the cytotoxic effects of chemotherapy drugs and transfer drug resistance to nearby cells [149]. TEVs are also necessary for regulation of immune cell physiological activity [150,151]. Circulating sEVs, derivedfrom the TME, contain proteins that promote immune tolerance, and thereby immune escape (Figure 3).

Through the analysis of cancer patient body fluids, sEVs have been shown to have huge potential as noninvasive markers applicable to cancer diagnosis, screening, and monitoring, particularly using miRNAs and miRNA clusters (Table 3). sEV-derived miRNAs have the potential to be noninvasive biomarkers that indicate disease progression; for example, a group of sEVs miRNAs, including let-7a, miR-1229, miR-1246, miR-150, miR-21, miR-223, and miR-23a, can be used as diagnostic biomarkers for colon cancer [116]. In addition, among various sEVs, miRNA clusters are vital in cancer diagnosis. For example, the miR-17/92 cluster, which includes six miRNAs (miR-17-5p, miR-18a-5p, miR-19a-3p, miR19b-1-5p, miR-20a-5p and miR-92a-1-5p) was selected as a potential diagnostic candidate marker for the diagnosis of non-NSCLC [152]. In many studies, sEVs containing specific miRNA clusters were genetically engineered for use in clinical practice, indicating the huge potential for the use of miRNA clusters in clinical cancer diagnosis and treatment [153].

As biomarkers, sEVs can provide rich, stable, sensitive, and specific biological information; they are a type of liquid biopsy specimen with high translational clinical value. Hence, the establishment of highly sensitive and rapid EV analysis technology is necessary for the development of liquid biopsies and methods for treatment with EVs. A highly sensitive and rapid analytic technology, termed ExoScreen, has been established to analyze surface proteins in extracellular vesicles from patient blood samples to identify CRC biomarkers. ExoScreen can monitor circulating EVs in serum without the need for purification steps. In addition to being a new liquid biopsy platform for detecting circulating EVs, ExoScreen can also help to diagnose various diseases and to identify biomarkers are important for new drug development [154]. 


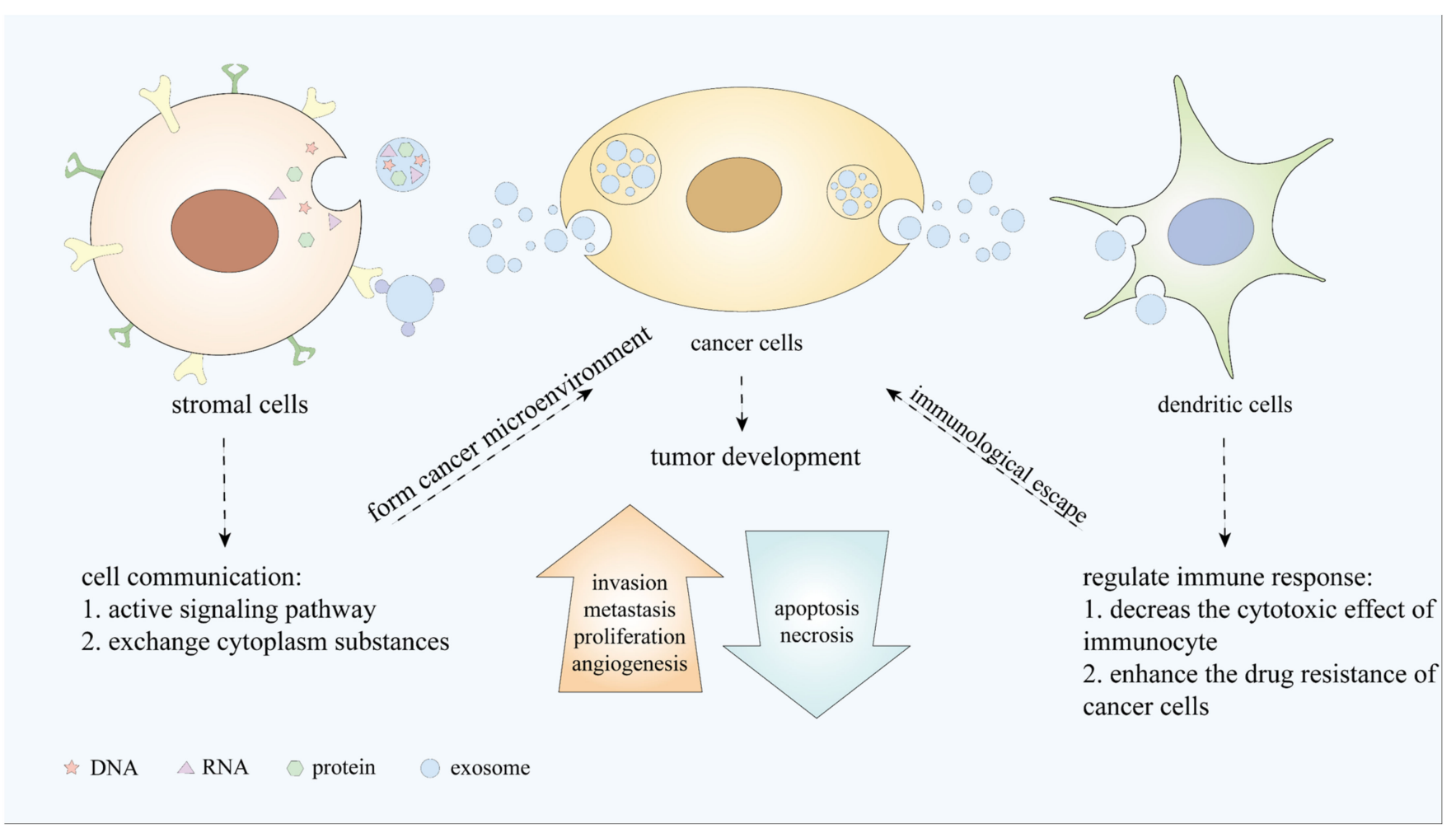

Figure 3. sEVs play an important role in cell communication, tumor development, and immune response.

Table 3. The potential of sEVs as cancer biomarkers in clinical practice.

\begin{tabular}{|c|c|c|c|c|c|}
\hline Cancers & sEVs Biomarkers & Analysis & Application & Sample Source & Reference \\
\hline Bladder Cancer & miR-21-5p, miR-141-3p and miR-205-5p & qRT-PCR & diagnostic & urine & [133] \\
\hline Bladder Cancer & miR-19b1-5p, 136-3p, 139-5p & qRT-PCR & diagnostic & urine & [134] \\
\hline Breast cancer & miR-21 & qRT-PCR & diagnostic & plasma & [106] \\
\hline Breast cancer & miR-1246 & qRT-PCR & $\begin{array}{l}\text { diagnostic and } \\
\text { prognosis }\end{array}$ & plasma & [107] \\
\hline Breast cancer & $\begin{array}{c}\text { miR-106a-5p, miR-106a-363 cluster } \\
\text { (miR-19b-3p, miR-20b-5p and miR-92a-3p) }\end{array}$ & qRT-PCR & diagnostic & plasma & [155] \\
\hline Breast cancer & miR-1280, miR-1260, and miR-720 & qRT-PCR & diagnostic & serum & [156] \\
\hline Breast cancer & Endothelial Locus-1 (Del-1) & ELISA & diagnostic & plasma & [108] \\
\hline Cervical cancer & DEmiR (miR-30d-5p and let-7d-3p) & ddPCR & diagnostic & plasma & [129] \\
\hline Cervical cancer & lncRNA HOTAIR, MALAT1 & qRT-PCR & $\begin{array}{l}\text { diagnostic and } \\
\text { therapeutic }\end{array}$ & $\begin{array}{c}\text { cervicovaginal } \\
\text { lavage specimens }\end{array}$ & [130] \\
\hline Cervical cancer & lncRNA MEG3 & qRT-PCR & $\begin{array}{l}\text { diagnostic and } \\
\text { therapeutic }\end{array}$ & $\begin{array}{l}\text { cervicovaginal } \\
\text { lavage specimens }\end{array}$ & [130] \\
\hline Colorectal cancer & lncRNA CRNDE-h & qRT-PCR & diagnostic & serum & [115] \\
\hline Colorectal cancer & lncRNA RPPH1 & qRT-PCR & diagnostic & plasma & [114] \\
\hline Colorectal cancer & $\begin{array}{l}\text { let-7a, miR-1229, miR-1246, miR-150, } \\
\text { miR-21, miR-223and miR-23a }\end{array}$ & qRT-PCR & diagnostic & plasma & [116] \\
\hline Colorectal cancer & TSPAN1 & qRT-PCR & diagnostic & plasma & [117] \\
\hline $\begin{array}{l}\text { Diffuse large B cell } \\
\text { lymphoma }\end{array}$ & miR-99a-5p and miR-125b-5p & qRT-PCR & prognosis & serum & [134] \\
\hline $\begin{array}{l}\text { Diffuse large B cell } \\
\text { lymphoma }\end{array}$ & $\operatorname{miR}-451 \mathrm{a}$ & qRT-PCR & therapy & serum & [137] \\
\hline $\begin{array}{l}\text { Diffuse large B cell } \\
\text { lymphoma }\end{array}$ & miR-155 and miR-21 & qRT-PCR & diagnostic & serum & [138] \\
\hline $\begin{array}{l}\text { Endometrial } \\
\text { cancer }\end{array}$ & $\operatorname{miR}-200 \mathrm{c}$ & qRT-PCR & diagnostic & urine & [145] \\
\hline
\end{tabular}


Table 3. Cont.

\begin{tabular}{|c|c|c|c|c|c|}
\hline Cancers & sEVs Biomarkers & Analysis & Application & Sample Source & Reference \\
\hline $\begin{array}{l}\text { Endometrial } \\
\text { cancer }\end{array}$ & miR-21 & meta-analysis & prognosis & serum & [146] \\
\hline Gastric cancer & miR-374a-5p; & qRT-PCR & prognosis & serum & [119] \\
\hline Gastric cancer & $\operatorname{miR}-217$ & qRT-PCR & diagnostic & serum & [119] \\
\hline Gastric cancer & lnc UEGC & qRT-PCR & diagnostic & plasma & [121] \\
\hline Liver cancer & miR-21 & qRT-PCR & diagnostic & serum & [125] \\
\hline Liver cancer & lncRNA HEIH & qRT-PCR & diagnostic & serum & [126] \\
\hline Liver cancer & lncRNA ATB & qRT-PCR & $\begin{array}{l}\text { diagnostic and } \\
\text { prognosis }\end{array}$ & serum & [126] \\
\hline Lung cancer & $\operatorname{miR}-96$ & qRT-PCR & $\begin{array}{l}\text { diagnostic or } \\
\text { therapeutic }\end{array}$ & serum & [103] \\
\hline Lung cancer $(\mathrm{AC})$ & $\begin{array}{l}\text { miR-181-5p, miR-30a-3p, miR-30e-3p } \\
\text { and miR-361-5p }\end{array}$ & qRT-PCR & diagnostic & serum & [104] \\
\hline Lung cancer (SCC) & miR-10b-5p, miR-15b-5p and miR-320b & qRT-PCR & diagnostic & serum & [104] \\
\hline Lung cancer & $\operatorname{lncRNA~UFC1}$ & qRT-PCR & prognostic & serum & [95] \\
\hline Lung cancer & leucine-rich $\alpha$-2-glycoprotein (LRG1) & $\begin{array}{l}\text { proteomic } \\
\text { identification }\end{array}$ & diagnostic & urinary & [100] \\
\hline Pancreatic cancer & GPC1 + crExos & qRT-PCR & diagnostic & serum & [141] \\
\hline Pancreatic cancer & miR-196a and miR-1246 & qRT-PCR & prognosis & plasma & [142] \\
\hline Prostate cancer & miR-82 of miR-183 cluster & qRT-PCR & prognostic & serum & [111] \\
\hline Prostate cancer & miR- 1290 & qRT-PCR & prognostic & plasma & [87] \\
\hline Prostate cancer & $\operatorname{miR}-1246$ & NanoString & diagnostic & serum & [112] \\
\hline
\end{tabular}

\section{Conclusions}

With advances in precision medicine, traditional solid biopsy has shown considerable limitations, while the emergence of liquid biopsy has substantially compensated for these, providing a promising platform for non-invasive diagnosis and prognosis techniques. In this review, we described the biogenesis of sEVs and the main mechanisms of sEV-mediated transfer and chemical resistance. Understanding the molecular mechanisms involved in $\mathrm{sEV}$ biogenesis, and their roles in metastasis and chemoresistance, will provide insights into the design of new therapies for sEV-mediated tumor metastasis and chemoresistance. Nevertheless, sEVs are involved in numerous pathophysiological conditions. Currently, cancer treatment research based on sEVs still needs to solve the problem of sEV loading with therapeutic agents (including functional proteins, miRNAs and various chemotherapeutics). Furthermore, more clinical trials are needed to verify the feasibility of sEVs disease screening and monitoring biomarker.

Funding: This work was supported by the National Natural Science Foundation of China (No. 31860317, No.32160169) and the National natural science foundation of Jiangxi province (No. 20202BAB206056), as well as the postgraduates innovation special fund project of Nanchang University (No.YC2020-S049) and the college students innovation training program of Nanchang University (No. S202010403034).

Institutional Review Board Statement: Not applicable.

Informed Consent Statement: Not applicable.

Data Availability Statement: Not applicable.

Acknowledgments: We would like to appreciate WHO providing cancer related statistical data.

Conflicts of Interest: The author declare no conflict of interest. 


$\begin{array}{ll}\text { Abbreviations } & \\ \text { AC } & \text { adenocarcinoma } \\ \text { SCC } & \text { squamous cell carcinoma } \\ \text { leucine rich alpha-2-glycoprotein 1 } \\ \text { LRG1 } & \begin{array}{l}\text { actin filament associated protein 1 antisense RNA 1 } \\ \text { AFAP1-AS1 }\end{array} \\ \text { Del-1 } & \text { Endothelial Locus-1 } \\ \text { PCA3 } & \text { prostate cancer antigen 3 } \\ \text { RPPH1 } & \text { colorectal neoplasia differentially expressed-h } \\ \text { CRNDE-h } & \text { Tetraspanin 1 } \\ \text { TSPAN1 } & \text { HOXA transcript at the distal tip } \\ \text { HOTTIP } & \text { lncRNA up-regulated in the sEVs of gastric cancer } \\ \text { lnc UEGC } & \text { hepatocellular carcinoma up-regulated 51 EZH2-associated } \\ \text { HEIH } & \text { activated by tumor growth factor- } \beta \\ \text { ATB } & \text { HOX transcript antisense RNA } \\ \text { HOTAIR } & \text { Metastasis associated in lung adenocarcinoma transcript 1 } \\ \text { MALAT1 } & \text { Maternally expressed gene 3 } \\ \text { MEG3 } & \text { lymph node metastasis-associated transcript 2 } \\ \text { LNMAT2 } & \text { glypican-1 + circulating exosomes } \\ \text { GPC1 + crExos } & \text { lectin galactoside-binding soluble 3 binding protein } \\ \text { LGALS3BP } & \end{array}$

\section{References}

1. Siegel, R.L.; Miller, K.D.; Jemal, A. Cancer statistics, 2020. CA Cancer J. Clin. 2020, 70, 7-30. [CrossRef]

2. De Toro, J.; Herschlik, L.; Waldner, C.; Mongini, C. Emerging roles of exosomes in normal and pathological conditions: New insights for diagnosis and therapeutic applications. Front. Immunol. 2015, 6, 203. [CrossRef] [PubMed]

3. Möller, A.; Lobb, R.J. The evolving translational potential of small extracellular vesicles in cancer. Nat. Rev. Cancer 2020, 20, 697-709. [CrossRef] [PubMed]

4. Wortzel, I.; Dror, S.; Kenific, C.M.; Lyden, D. Exosome-Mediated Metastasis: Communication from a Distance. Dev. Cell 2019, 49, 347-360. [CrossRef]

5. Théry, C.; Witwer, K.W.; Aikawa, E.; Alcaraz, M.J.; Anderson, J.D.; Andriantsitohaina, R.; Antoniou, A.; Arab, T.; Archer, F.; Atkin-Smith, G.K.; et al. Minimal information for studies of extracellular vesicles 2018 (MISEV2018): A position statement of the International Society for Extracellular Vesicles and update of the MISEV2014 guidelines. J. Extracell. Vesicles 2018, 7, 1535750. [CrossRef] [PubMed]

6. Kowal, J.; Arras, G.; Colombo, M.; Jouve, M.; Morath, J.P.; Primdal-Bengtson, B.; Dingli, F.; Loew, D.; Tkach, M.; Théry, C. Proteomic comparison defines novel markers to characterize heterogeneous populations of extracellular vesicle subtypes. Proc. Natl. Acad. Sci. USA 2016, 113, E968-E977. [CrossRef]

7. Kalluri, R.; LeBleu, V.S. The biology, function, and biomedical applications of exosomes. Science 2020, 367, 16. [CrossRef]

8. Ratajczak, M.Z.; Ratajczak, J. Extracellular microvesicles/exosomes: Discovery, disbelief, acceptance, and the future? Leukemia 2020, 34, 3126-3135. [CrossRef]

9. Ludwig, N.; Rubenich, D.S.; Zaręba, Ł.; Siewiera, J.; Pieper, J.; Braganhol, E.; Reichert, T.E.; Szczepański, M.J. Potential Roles of Tumor Cell- and Stroma Cell-Derived Small Extracellular Vesicles in Promoting a Pro-Angiogenic Tumor Microenvironment. Cancers 2020, 12, 3599. [CrossRef]

10. Kaiser, J. Malignant messengers. Science 2016, 352, 164-166. [CrossRef]

11. Ono, M.; Kosaka, N.; Tominaga, N.; Yoshioka, Y.; Takeshita, F.; Takahashi, R.U.; Yoshida, M.; Tsuda, H.; Tamura, K.; Ochiya, T. Exosomes from bone marrow mesenchymal stem cells contain a microRNA that promotes dormancy in metastatic breast cancer cells. Sci. Signal. 2014, 7, ra63. [CrossRef]

12. Braicu, C.; Tomuleasa, C.; Monroig, P.; Cucuianu, A.; Berindan-Neagoe, I.; Calin, G.A. Exosomes as divine messengers: Are they the Hermes of modern molecular oncology? Cell Death Differ. 2015, 22, 34-45. [CrossRef] [PubMed]

13. Pavlova, N.N.; Thompson, C.B. The Emerging Hallmarks of Cancer Metabolism. Cell Metab. 2016, 23, 27-47. [CrossRef]

14. Kanada, M.; Bachmann, M.H.; Contag, C.H. Signaling by Extracellular Vesicles Advances Cancer Hallmarks. Trends Cancer 2016, 2, 84-94. [CrossRef] [PubMed]

15. Kosaka, N. Decoding the Secret of Cancer by Means of Extracellular Vesicles. J. Clin. Med. 2016, 5, 22. [CrossRef]

16. Ciardiello, C.; Cavallini, L.; Spinelli, C.; Yang, J.; Reis-Sobreiro, M.; de Candia, P.; Minciacchi, V.R.; Di Vizio, D. Focus on Extracellular Vesicles: New Frontiers of Cell-to-Cell Communication in Cancer. Int. J. Mol. Sci. 2016, 17, 175. [CrossRef]

17. Falasca, M.; Kim, M.; Casari, I. Pancreatic cancer: Current research and future directions. Biochim. Biophys. Acta 2016, 1865, 123-132. [CrossRef] [PubMed]

18. Shao, H.; Chung, J.; Issadore, D. Diagnostic technologies for circulating tumour cells and exosomes. Biosci. Rep. 2015, 36, e00292. [CrossRef] 
19. Robbins, P.D.; Morelli, A.E. Regulation of immune responses by extracellular vesicles. Nat. Rev. Immunol. 2014, 14, 195-208. [CrossRef]

20. Hannafon, B.N.; Ding, W.Q. Intercellular communication by exosome-derived microRNAs in cancer. Int. J. Mol. Sci. 2013, 14, 14240-14269. [CrossRef]

21. Sadovska, L.; Eglītis, J.; Linē, A. Extracellular Vesicles as Biomarkers and Therapeutic Targets in Breast Cancer. Anticancer Res. 2015, 35, 6379-6390. [PubMed]

22. Thind, A.; Wilson, C. Exosomal miRNAs as cancer biomarkers and therapeutic targets. J. Extracell. Vesicles 2016, 5, 31292. [CrossRef] [PubMed]

23. Lai, X.; Wang, M.; McElyea, S.D.; Sherman, S.; House, M.; Korc, M. A microRNA signature in circulating exosomes is superior to exosomal glypican-1 levels for diagnosing pancreatic cancer. Cancer Lett. 2017, 393, 86-93. [CrossRef] [PubMed]

24. Soung, Y.H.; Ford, S.; Zhang, V.; Chung, J. Exosomes in Cancer Diagnostics. Cancers 2017, 9, 8. [CrossRef]

25. Fabbri, M.; Paone, A.; Calore, F.; Galli, R.; Gaudio, E.; Santhanam, R.; Lovat, F.; Fadda, P.; Mao, C.; Nuovo, G.J.; et al. MicroRNAs bind to Toll-like receptors to induce prometastatic inflammatory response. Proc. Natl. Acad. Sci. USA 2012, 109, E2110-E2116. [CrossRef]

26. György, B.; Szabó, T.G.; Pásztói, M.; Pál, Z.; Misják, P.; Aradi, B.; László, V.; Pállinger, E.; Pap, E.; Kittel, A.; et al. Membrane vesicles, current state-of-the-art: Emerging role of extracellular vesicles. Cell. Mol. Life Sci. 2011, 68, 2667-2688. [CrossRef]

27. Yue, B.; Yang, H.; Wang, J.; Ru, W.; Wu, J.; Huang, Y.; Lan, X.; Lei, C.; Chen, H. Exosome biogenesis, secretion and function of exosomal miRNAs in skeletal muscle myogenesis. Cell Prolif. 2020, 53, e12857. [CrossRef]

28. Tschuschke, M.; Kocherova, I.; Bryja, A.; Mozdziak, P.; Angelova Volponi, A.; Janowicz, K.; Sibiak, R.; Piotrowska-Kempisty, H.; Iżycki, D.; Bukowska, D.; et al. Inclusion Biogenesis, Methods of Isolation and Clinical Application of Human Cellular Exosomes. J. Clin. Med. 2020, 9, 436. [CrossRef]

29. Xie, F.; Zhou, X.; Fang, M.; Li, H.; Su, P.; Tu, Y.; Zhang, L.; Zhou, F. Extracellular Vesicles in Cancer Immune Microenvironment and Cancer Immunotherapy. Adv. Sci. 2019, 6, 1901779. [CrossRef]

30. Negahdaripour, M.; Owji, H.; Eskandari, S.; Zamani, M.; Vakili, B.; Nezafat, N. Small extracellular vesicles (sEVs): Discovery, functions, applications, detection methods and various engineered forms. Expert Opin. Biol. Ther. 2021, 21, 371-394. [CrossRef]

31. Takakura, Y.; Matsumoto, A.; Takahashi, Y. Therapeutic Application of Small Extracellular Vesicles (sEVs): Pharmaceutical and Pharmacokinetic Challenges. Biol. Pharm. Bull. 2020, 43, 576-583. [CrossRef]

32. Ghafouri-Fard, S.; Niazi, V.; Hussen, B.M.; Omrani, M.D.; Taheri, M.; Basiri, A. The Emerging Role of Exosomes in the Treatment of Human Disorders With a Special Focus on Mesenchymal Stem Cells-Derived Exosomes. Front. Cell Dev. Biol. 2021, 9, 653296. [CrossRef] [PubMed]

33. Mashouri, L.; Yousefi, H.; Aref, A.R.; Ahadi, A.M.; Molaei, F.; Alahari, S.K. Exosomes: Composition, biogenesis, and mechanisms in cancer metastasis and drug resistance. Mol. Cancer 2019, 18, 75. [CrossRef]

34. Todorova, D.; Simoncini, S.; Lacroix, R.; Sabatier, F.; Dignat-George, F. Extracellular Vesicles in Angiogenesis. Circ. Res. 2017, 120, 1658-1673. [CrossRef] [PubMed]

35. Olejarz, W.; Kubiak-Tomaszewska, G.; Chrzanowska, A.; Lorenc, T. Exosomes in Angiogenesis and Anti-angiogenic Therapy in Cancers. Int. J. Mol. Sci. 2020, 21, 5840. [CrossRef]

36. Skog, J.; Würdinger, T.; van Rijn, S.; Meijer, D.H.; Gainche, L.; Sena-Esteves, M.; Curry, W.T., Jr.; Carter, B.S.; Krichevsky, A.M.; Breakefield, X.O. Glioblastoma microvesicles transport RNA and proteins that promote tumour growth and provide diagnostic biomarkers. Nat. Cell Biol. 2008, 10, 1470-1476. [CrossRef] [PubMed]

37. Maji, S.; Chaudhary, P.; Akopova, I.; Nguyen, P.M.; Hare, R.J.; Gryczynski, I.; Vishwanatha, J.K. Exosomal Annexin II Promotes Angiogenesis and Breast Cancer Metastasis. Mol. Cancer Res. 2017, 15, 93-105. [CrossRef] [PubMed]

38. Lu, J.; Li, J.; Liu, S.; Wang, T.; Ianni, A.; Bober, E.; Braun, T.; Xiang, R.; Yue, S. Exosomal tetraspanins mediate cancer metastasis by altering host microenvironment. Oncotarget 2017, 8, 62803-62815. [CrossRef]

39. Choi, D.S.; Park, J.O.; Jang, S.C.; Yoon, Y.J.; Jung, J.W.; Choi, D.Y.; Kim, J.W.; Kang, J.S.; Park, J.; Hwang, D.; et al. Proteomic analysis of microvesicles derived from human colorectal cancer ascites. Proteomics 2011, 11, 2745-2751. [CrossRef]

40. Shen, L.; Chen, G.; Xia, Q.; Shao, S.; Fang, H. Exosomal miR-200 family as serum biomarkers for early detection and prognostic prediction of cholangiocarcinoma. Int. J. Clin. Exp. Pathol. 2019, 12, 3870-3876. [PubMed]

41. Kim, H.; Lee, S.; Shin, E.; Seong, K.M.; Jin, Y.W.; Youn, H.; Youn, B. The Emerging Roles of Exosomes as EMT Regulators in Cancer. Cells 2020, 9, 861. [CrossRef]

42. Lin, Q.; Zhou, C.R.; Bai, M.J.; Zhu, D.; Chen, J.W.; Wang, H.F.; Li, M.A.; Wu, C.; Li, Z.R.; Huang, M.S. Exosome-mediated miRNA delivery promotes liver cancer EMT and metastasis. Am. J. Transl. Res. 2020, 12, 1080-1095. [PubMed]

43. Pretzsch, E.; Bösch, F.; Neumann, J.; Ganschow, P.; Bazhin, A.; Guba, M.; Werner, J.; Angele, M. Mechanisms of Metastasis in Colorectal Cancer and Metastatic Organotropism: Hematogenous versus Peritoneal Spread. J. Oncol. 2019, $2019,7407190$. [CrossRef] [PubMed]

44. Wang, Z.; Chen, J.Q.; Liu, J.L.; Tian, L. Exosomes in tumor microenvironment: Novel transporters and biomarkers. J. Transl. Med. 2016, 14, 297. [CrossRef]

45. Zhang, H.; Deng, T.; Liu, R.; Bai, M.; Zhou, L.; Wang, X.; Li, S.; Wang, X.; Yang, H.; Li, J.; et al. Exosome-delivered EGFR regulates liver microenvironment to promote gastric cancer liver metastasis. Nat. Commun. 2017, 8, 15016. [CrossRef] [PubMed] 
46. Armacki, M.; Polaschek, S.; Waldenmaier, M.; Morawe, M.; Ruhland, C.; Schmid, R.; Lechel, A.; Tharehalli, U.; Steup, C.; Bektas, Y.; et al. Protein Kinase D1, Reduced in Human Pancreatic Tumors, Increases Secretion of Small Extracellular Vesicles From Cancer Cells That Promote Metastasis to Lung in Mice. Gastroenterology 2020, 159, 1019-1035.e1022. [CrossRef] [PubMed]

47. Jotzu, C.; Alt, E.; Welte, G.; Li, J.; Hennessy, B.T.; Devarajan, E.; Krishnappa, S.; Pinilla, S.; Droll, L.; Song, Y.H. Adipose tissue derived stem cells differentiate into carcinoma-associated fibroblast-like cells under the influence of tumor derived factors. Cell Oncol. 2011, 34, 55-67. [CrossRef]

48. Pace, K.R.; Dutt, R.; Galileo, D.S. Exosomal L1CAM Stimulates Glioblastoma Cell Motility, Proliferation, and Invasiveness. Int. J. Mol. Sci. 2019, 20, 3982. [CrossRef]

49. Arscott, W.T.; Tandle, A.T.; Zhao, S.; Shabason, J.E.; Gordon, I.K.; Schlaff, C.D.; Zhang, G.; Tofilon, P.J.; Camphausen, K.A. Ionizing radiation and glioblastoma exosomes: Implications in tumor biology and cell migration. Transl. Oncol. 2013, 6, 638-648. [CrossRef]

50. Wieckowski, E.U.; Visus, C.; Szajnik, M.; Szczepanski, M.J.; Storkus, W.J.; Whiteside, T.L. Tumor-derived microvesicles promote regulatory $\mathrm{T}$ cell expansion and induce apoptosis in tumor-reactive activated CD8+ T lymphocytes. J. Immunol. 2009, 183, 3720-3730. [CrossRef]

51. Whiteside, T.L. Tumor-Derived Exosomes and Their Role in Cancer Progression. Adv. Clin. Chem. 2016, 74, 103-141. [CrossRef] [PubMed]

52. Czystowska, M.; Han, J.; Szczepanski, M.J.; Szajnik, M.; Quadrini, K.; Brandwein, H.; Hadden, J.W.; Signorelli, K.; Whiteside, T.L. IRX-2, a novel immunotherapeutic, protects human T cells from tumor-induced cell death. Cell Death Differ. 2009, 16, 708-718. [CrossRef] [PubMed]

53. Swartz, M.A.; Iida, N.; Roberts, E.W.; Sangaletti, S.; Wong, M.H.; Yull, F.E.; Coussens, L.M.; DeClerck, Y.A. Tumor microenvironment complexity: Emerging roles in cancer therapy. Cancer Res. 2012, 72, 2473-2480. [CrossRef] [PubMed]

54. Hu, J.L.; Wang, W.; Lan, X.L.; Zeng, Z.C.; Liang, Y.S.; Yan, Y.R.; Song, F.Y.; Wang, F.F.; Zhu, X.H.; Liao, W.J.; et al. CAFs secreted exosomes promote metastasis and chemotherapy resistance by enhancing cell stemness and epithelial-mesenchymal transition in colorectal cancer. Mol. Cancer 2019, 18, 91. [CrossRef]

55. Webber, J.P.; Spary, L.K.; Sanders, A.J.; Chowdhury, R.; Jiang, W.G.; Steadman, R.; Wymant, J.; Jones, A.T.; Kynaston, H.; Mason, M.D.; et al. Differentiation of tumour-promoting stromal myofibroblasts by cancer exosomes. Oncogene 2015, 34, 290-302. [CrossRef]

56. Webber, J.; Steadman, R.; Mason, M.D.; Tabi, Z.; Clayton, A. Cancer exosomes trigger fibroblast to myofibroblast differentiation. Cancer Res. 2010, 70, 9621-9630. [CrossRef]

57. Cho, J.A.; Park, H.; Lim, E.H.; Lee, K.W. Exosomes from breast cancer cells can convert adipose tissue-derived mesenchymal stem cells into myofibroblast-like cells. Int. J. Oncol. 2012, 40, 130-138. [CrossRef]

58. Hu, Y.; Yan, C.; Mu, L.; Huang, K.; Li, X.; Tao, D.; Wu, Y.; Qin, J. Fibroblast-Derived Exosomes Contribute to Chemoresistance through Priming Cancer Stem Cells in Colorectal Cancer. PLoS ONE 2015, 10, e0125625. [CrossRef]

59. Boelens, M.C.; Wu, T.J.; Nabet, B.Y.; Xu, B.; Qiu, Y.; Yoon, T.; Azzam, D.J.; Twyman-Saint Victor, C.; Wiemann, B.Z.; Ishwaran, H.; et al. Exosome transfer from stromal to breast cancer cells regulates therapy resistance pathways. Cell 2014, 159, 499-513. [CrossRef]

60. Torreggiani, E.; Roncuzzi, L.; Perut, F.; Zini, N.; Baldini, N. Multimodal transfer of MDR by exosomes in human osteosarcoma. Int. J. Oncol. 2016, 49, 189-196. [CrossRef]

61. Ji, R.; Zhang, B.; Zhang, X.; Xue, J.; Yuan, X.; Yan, Y.; Wang, M.; Zhu, W.; Qian, H.; Xu, W. Exosomes derived from human mesenchymal stem cells confer drug resistance in gastric cancer. Cell Cycle 2015, 14, 2473-2483. [CrossRef] [PubMed]

62. Xu, J.; Liao, K.; Zhou, W. Exosomes Regulate the Transformation of Cancer Cells in Cancer Stem Cell Homeostasis. Stem Cells Int. 2018, 2018, 4837370. [CrossRef]

63. Kim, W.T.; Ryu, C.J. Cancer stem cell surface markers on normal stem cells. BMB Rep. 2017, 50, 285-298. [CrossRef]

64. López de Andrés, J.; Griñán-Lisón, C.; Jiménez, G.; Marchal, J.A. Cancer stem cell secretome in the tumor microenvironment: A key point for an effective personalized cancer treatment. J. Hematol. Oncol. 2020, 13, 136. [CrossRef]

65. Chang, J.C. Cancer stem cells: Role in tumor growth, recurrence, metastasis, and treatment resistance. Medicine 2016, 95, S20-S25. [CrossRef] [PubMed]

66. Ayob, A.Z.; Ramasamy, T.S. Cancer stem cells as key drivers of tumour progression. J. Biomed. Sci. 2018, 25, 20. [CrossRef]

67. Lindoso, R.S.; Collino, F.; Vieyra, A. Extracellular vesicles as regulators of tumor fate: Crosstalk among cancer stem cells, tumor cells and mesenchymal stem cells. Stem Cell Investig. 2017, 4, 75. [CrossRef]

68. Santos, J.C.; Lima, N.D.S.; Sarian, L.O.; Matheu, A.; Ribeiro, M.L.; Derchain, S.F.M. Exosome-mediated breast cancer chemoresistance via miR-155 transfer. Sci. Rep. 2018, 8, 829. [CrossRef]

69. Yang, Z.; Zhao, N.; Cui, J.; Wu, H.; Xiong, J.; Peng, T. Exosomes derived from cancer stem cells of gemcitabine-resistant pancreatic cancer cells enhance drug resistance by delivering miR-210. Cell Oncol. 2020, 43, 123-136. [CrossRef] [PubMed]

70. Chen, Y.; Song, Y.; Du, W.; Gong, L.; Chang, H.; Zou, Z. Tumor-associated macrophages: An accomplice in solid tumor progression. J. Biomed. Sci. 2019, 26, 78. [CrossRef]

71. Netea-Maier, R.T.; Smit, J.W.A.; Netea, M.G. Metabolic changes in tumor cells and tumor-associated macrophages: A mutual relationship. Cancer Lett. 2018, 413, 102-109. [CrossRef] [PubMed] 
72. Fang, W.B.; Yao, M.; Brummer, G.; Acevedo, D.; Alhakamy, N.; Berkland, C.; Cheng, N. Targeted gene silencing of CCL2 inhibits triple negative breast cancer progression by blocking cancer stem cell renewal and M2 macrophage recruitment. Oncotarget 2016, 7, 49349-49367. [CrossRef] [PubMed]

73. Zheng, P.; Chen, L.; Yuan, X.; Luo, Q.; Liu, Y.; Xie, G.; Ma, Y.; Shen, L. Exosomal transfer of tumor-associated macrophage-derived miR-21 confers cisplatin resistance in gastric cancer cells. J. Exp. Clin. Cancer Res. 2017, 36, 53. [CrossRef] [PubMed]

74. Cooks, T.; Pateras, I.S.; Jenkins, L.M.; Patel, K.M.; Robles, A.I.; Morris, J.; Forshew, T.; Appella, E.; Gorgoulis, V.G.; Harris, C.C. Mutant p53 cancers reprogram macrophages to tumor supporting macrophages via exosomal miR-1246. Nat. Commun. 2018, 9, 771. [CrossRef]

75. Chen, X.; Ying, X.; Wang, X.; Wu, X.; Zhu, Q.; Wang, X. Exosomes derived from hypoxic epithelial ovarian cancer deliver microRNA-940 to induce macrophage M2 polarization. Oncol. Rep. 2017, 38, 522-528. [CrossRef]

76. Chen, X.; Zhou, J.; Li, X.; Wang, X.; Lin, Y.; Wang, X. Exosomes derived from hypoxic epithelial ovarian cancer cells deliver microRNAs to macrophages and elicit a tumor-promoted phenotype. Cancer Lett. 2018, 435, 80-91. [CrossRef]

77. Lin, F.; Yin, H.B.; Li, X.Y.; Zhu, G.M.; He, W.Y.; Gou, X. Bladder cancer cell-secreted exosomal miR-21 activates the PI3K/AKT pathway in macrophages to promote cancer progression. Int. J. Oncol. 2020, 56, 151-164. [CrossRef]

78. Park, J.E.; Dutta, B.; Tse, S.W.; Gupta, N.; Tan, C.F.; Low, J.K.; Yeoh, K.W.; Kon, O.L.; Tam, J.P.; Sze, S.K. Hypoxia-induced tumor exosomes promote M2-like macrophage polarization of infiltrating myeloid cells and microRNA-mediated metabolic shift. Oncogene 2019, 38, 5158-5173. [CrossRef]

79. Keller, S.; Ridinger, J.; Rupp, A.K.; Janssen, J.W.; Altevogt, P. Body fluid derived exosomes as a novel template for clinical diagnostics. J. Transl. Med. 2011, 9, 86. [CrossRef]

80. Gurunathan, S.; Kang, M.H.; Jeyaraj, M.; Qasim, M.; Kim, J.H. Review of the Isolation, Characterization, Biological Function, and Multifarious Therapeutic Approaches of Exosomes. Cells 2019, 8, 307. [CrossRef]

81. Romano, G.; Veneziano, D.; Acunzo, M.; Croce, C.M. Small non-coding RNA and cancer. Carcinogenesis 2017, 38, 485-491. [CrossRef] [PubMed]

82. Meng, X.; Müller, V.; Milde-Langosch, K.; Trillsch, F.; Pantel, K.; Schwarzenbach, H. Diagnostic and prognostic relevance of circulating exosomal miR-373, miR-200a, miR-200b and miR-200c in patients with epithelial ovarian cancer. Oncotarget 2016, 7, 16923-16935. [CrossRef]

83. Yokoi, A.; Matsuzaki, J.; Yamamoto, Y.; Yoneoka, Y.; Takahashi, K.; Shimizu, H.; Uehara, T.; Ishikawa, M.; Ikeda, S.I.; Sonoda, T.; et al. Integrated extracellular microRNA profiling for ovarian cancer screening. Nat. Commun. 2018, 9, 4319. [CrossRef]

84. Liu, C.; Zhou, X.; Long, Q.; Zeng, H.; Sun, Q.; Chen, Y.; Wu, D.; Liu, L. Small extracellular vesicles containing miR-30a-3p attenuate the migration and invasion of hepatocellular carcinoma by targeting SNAP23 gene. Oncogene 2021, 40, 233-245. [CrossRef] [PubMed]

85. Cho, H.J.; Eun, J.W.; Baek, G.O.; Seo, C.W.; Ahn, H.R.; Kim, S.S.; Cho, S.W.; Cheong, J.Y. Serum Exosomal MicroRNA, miR-10b-5p, as a Potential Diagnostic Biomarker for Early-Stage Hepatocellular Carcinoma. J. Clin. Med. 2020, 9, 281. [CrossRef]

86. Eichelser, C.; Stückrath, I.; Müller, V.; Milde-Langosch, K.; Wikman, H.; Pantel, K.; Schwarzenbach, H. Increased serum levels of circulating exosomal microRNA-373 in receptor-negative breast cancer patients. Oncotarget 2014, 5, 9650-9663. [CrossRef]

87. Huang, X.; Yuan, T.; Liang, M.; Du, M.; Xia, S.; Dittmar, R.; Wang, D.; See, W.; Costello, B.A.; Quevedo, F.; et al. Exosomal miR-1290 and miR-375 as prognostic markers in castration-resistant prostate cancer. Eur. Urol. 2015, 67, 33-41. [CrossRef] [PubMed]

88. Shi, T.; Gao, G.; Cao, Y. Long Noncoding RNAs as Novel Biomarkers Have a Promising Future in Cancer Diagnostics. Dis. Markers 2016, 2016, 9085195. [CrossRef]

89. Gutschner, T.; Diederichs, S. The hallmarks of cancer: A long non-coding RNA point of view. RNA Biol. 2012, 9, 703-719. [CrossRef]

90. Ma, Y.; Yang, Y.; Wang, F.; Moyer, M.P.; Wei, Q.; Zhang, P.; Yang, Z.; Liu, W.; Zhang, H.; Chen, N.; et al. Long non-coding RNA CCAL regulates colorectal cancer progression by activating Wnt/beta-catenin signalling pathway via suppression of activator protein 2alpha. Gut 2016, 65, 1494-1504. [CrossRef] [PubMed]

91. Xue, M.; Chen, W.; Xiang, A.; Wang, R.; Chen, H.; Pan, J.; Pang, H.; An, H.; Wang, X.; Hou, H.; et al. Hypoxic exosomes facilitate bladder tumor growth and development through transferring long non-coding RNA-UCA1. Mol. Cancer 2017, 16, 143. [CrossRef]

92. Xu, H.; Han, H.; Song, S.; Yi, N.; Qian, C.; Qiu, Y.; Zhou, W.; Hong, Y.; Zhuang, W.; Li, Z.; et al. Exosome-Transmitted PSMA3 and PSMA3-AS1 Promote Proteasome Inhibitor Resistance in Multiple Myeloma. Clin. Cancer Res. 2019, 25, 1923-1935. [CrossRef] [PubMed]

93. Ren, J.; Ding, L.; Zhang, D.; Shi, G.; Xu, Q.; Shen, S.; Wang, Y.; Wang, T.; Hou, Y. Carcinoma-associated fibroblasts promote the stemness and chemoresistance of colorectal cancer by transferring exosomal lncRNA H19. Theranostics 2018, 8, 3932-3948. [CrossRef] [PubMed]

94. Han, M.; Gu, Y.; Lu, P.; Li, J.; Cao, H.; Li, X.; Qian, X.; Yu, C.; Yang, Y.; Yang, X.; et al. Exosome-mediated lncRNA AFAP1-AS1 promotes trastuzumab resistance through binding with AUF1 and activating ERBB2 translation. Mol. Cancer 2020, 19, 26. [CrossRef] [PubMed]

95. Zang, X.; Gu, J.; Zhang, J.; Shi, H.; Hou, S.; Xu, X.; Chen, Y.; Zhang, Y.; Mao, F.; Qian, H.; et al. Exosome-transmitted lncRNA UFC1 promotes non-small-cell lung cancer progression by EZH2-mediated epigenetic silencing of PTEN expression. Cell Death Dis. 2020, 11, 215. [CrossRef] [PubMed] 
96. Al-Nedawi, K.; Meehan, B.; Micallef, J.; Lhotak, V.; May, L.; Guha, A.; Rak, J. Intercellular transfer of the oncogenic receptor EGFRvIII by microvesicles derived from tumour cells. Nat. Cell Biol. 2008, 10, 619-624. [CrossRef]

97. Demory Beckler, M.; Higginbotham, J.N.; Franklin, J.L.; Ham, A.J.; Halvey, P.J.; Imasuen, I.E.; Whitwell, C.; Li, M.; Liebler, D.C.; Coffey, R.J. Proteomic analysis of exosomes from mutant KRAS colon cancer cells identifies intercellular transfer of mutant KRAS. Mol. Cell Proteom. 2013, 12, 343-355. [CrossRef] [PubMed]

98. Costa-Silva, B.; Aiello, N.M.; Ocean, A.J.; Singh, S.; Zhang, H.; Thakur, B.K.; Becker, A.; Hoshino, A.; Mark, M.T.; Molina, H.; et al Pancreatic cancer exosomes initiate pre-metastatic niche formation in the liver. Nat. Cell Biol. 2015, 17, 816-826. [CrossRef]

99. Nishigaki, T.; Takahashi, T.; Serada, S.; Fujimoto, M.; Ohkawara, T.; Hara, H.; Sugase, T.; Otsuru, T.; Saito, Y.; Tsujii, S.; et al. Anti-glypican-1 antibody-drug conjugate is a potential therapy against pancreatic cancer. Br. J. Cancer 2020, 122, $1333-1341$. [CrossRef] [PubMed]

100. Li, Y.; Zhang, Y.; Qiu, F.; Qiu, Z. Proteomic identification of exosomal LRG1: A potential urinary biomarker for detecting NSCLC. Electrophoresis 2011, 32, 1976-1983. [CrossRef]

101. Messenger, S.W.; Woo, S.S.; Sun, Z.; Martin, T.F.J. A Ca(2+)-stimulated exosome release pathway in cancer cells is regulated by Munc13-4. J. Cell Biol. 2018, 217, 2877-2890. [CrossRef] [PubMed]

102. Zheng, Q.; Ding, H.; Wang, L.; Yan, Y.; Wan, Y.; Yi, Y.; Tao, L.; Zhu, C. Circulating Exosomal miR-96 as a Novel Biomarker for Radioresistant Non-Small-Cell Lung Cancer. J. Oncol. 2021, 2021, 5893981. [CrossRef]

103. Wu, H.; Zhou, J.; Mei, S.; Wu, D.; Mu, Z.; Chen, B.; Xie, Y.; Ye, Y.; Liu, J. Circulating exosomal microRNA-96 promotes cell proliferation, migration and drug resistance by targeting LMO7. J. Cell Mol. Med. 2017, 21, 1228-1236. [CrossRef] [PubMed]

104. Jin, X.; Chen, Y.; Chen, H.; Fei, S.; Chen, D.; Cai, X.; Liu, L.; Lin, B.; Su, H.; Zhao, L.; et al. Evaluation of Tumor-Derived Exosomal miRNA as Potential Diagnostic Biomarkers for Early-Stage Non-Small Cell Lung Cancer Using Next-Generation Sequencing. Clin. Cancer Res. 2017, 23, 5311-5319. [CrossRef]

105. Jabbari, N.; Akbariazar, E.; Feqhhi, M.; Rahbarghazi, R.; Rezaie, J. Breast cancer-derived exosomes: Tumor progression and therapeutic agents. J. Cell Physiol. 2020, 235, 6345-6356. [CrossRef]

106. Wang, M.; Ji, S.; Shao, G.; Zhang, J.; Zhao, K.; Wang, Z.; Wu, A. Effect of exosome biomarkers for diagnosis and prognosis of breast cancer patients. Clin. Transl. Oncol. 2018, 20, 906-911. [CrossRef]

107. Hannafon, B.N.; Trigoso, Y.D.; Calloway, C.L.; Zhao, Y.D.; Lum, D.H.; Welm, A.L.; Zhao, Z.J.; Blick, K.E.; Dooley, W.C.; Ding, W.Q. Plasma exosome microRNAs are indicative of breast cancer. Breast Cancer Res. 2016, 18, 90. [CrossRef]

108. Moon, P.G.; Lee, J.E.; Cho, Y.E.; Lee, S.J.; Jung, J.H.; Chae, Y.S.; Bae, H.I.; Kim, Y.B.; Kim, I.S.; Park, H.Y.; et al. Identification of Developmental Endothelial Locus-1 on Circulating Extracellular Vesicles as a Novel Biomarker for Early Breast Cancer Detection. Clin. Cancer Res. 2016, 22, 1757-1766. [CrossRef]

109. Scott, E.; Munkley, J. Glycans as Biomarkers in Prostate Cancer. Int. J. Mol. Sci. 2019, 20, 1389. [CrossRef]

110. Litwin, M.S.; Tan, H.J. The Diagnosis and Treatment of Prostate Cancer: A Review. JAMA 2017, 317, 2532-2542. [CrossRef] [PubMed]

111. Mihelich, B.L.; Dambal, S.; Lin, S.; Nonn, L. miR-182, of the miR-183 cluster family, is packaged in exosomes and is detected in human exosomes from serum, breast cells and prostate cells. Oncol. Lett. 2016, 12, 1197-1203. [CrossRef]

112. Bhagirath, D.; Yang, T.L.; Bucay, N.; Sekhon, K.; Majid, S.; Shahryari, V.; Dahiya, R.; Tanaka, Y.; Saini, S. microRNA-1246 Is an Exosomal Biomarker for Aggressive Prostate Cancer. Cancer Res. 2018, 78, 1833-1844. [CrossRef] [PubMed]

113. Ferlay, J.; Colombet, M.; Soerjomataram, I.; Dyba, T.; Randi, G.; Bettio, M.; Gavin, A.; Visser, O.; Bray, F. Cancer incidence and mortality patterns in Europe: Estimates for 40 countries and 25 major cancers in 2018. Eur. J. Cancer 2018, 103, 356-387. [CrossRef] [PubMed]

114. Liang, Z.X.; Liu, H.S.; Wang, F.W.; Xiong, L.; Zhou, C.; Hu, T.; He, X.W.; Wu, X.J.; Xie, D.; Wu, X.R.; et al. LncRNA RPPH1 promotes colorectal cancer metastasis by interacting with TUBB3 and by promoting exosomes-mediated macrophage M2 polarization. Cell Death Dis. 2019, 10, 829. [CrossRef]

115. Liu, T.; Zhang, X.; Gao, S.; Jing, F.; Yang, Y.; Du, L.; Zheng, G.; Li, P.; Li, C.; Wang, C. Exosomal long noncoding RNA CRNDE-h as a novel serum-based biomarker for diagnosis and prognosis of colorectal cancer. Oncotarget 2016, 7, 85551-85563. [CrossRef]

116. Ogata-Kawata, H.; Izumiya, M.; Kurioka, D.; Honma, Y.; Yamada, Y.; Furuta, K.; Gunji, T.; Ohta, H.; Okamoto, H.; Sonoda, H.; et al. Circulating exosomal microRNAs as biomarkers of colon cancer. PLoS ONE 2014, 9, e92921. [CrossRef]

117. Lee, C.H.; Im, E.J.; Moon, P.G.; Baek, M.C. Discovery of a diagnostic biomarker for colon cancer through proteomic profiling of small extracellular vesicles. BMC Cancer 2018, 18, 1058. [CrossRef]

118. Allemani, C.; Weir, H.K.; Carreira, H.; Harewood, R.; Spika, D.; Wang, X.S.; Bannon, F.; Ahn, J.V.; Johnson, C.J.; Bonaventure, A.; et al. Global surveillance of cancer survival 1995-2009: Analysis of individual data for 25,676,887 patients from 279 populationbased registries in 67 countries (CONCORD-2). Lancet 2015, 385, 977-1010. [CrossRef]

119. Ji, R.; Zhang, X.; Gu, H.; Ma, J.; Wen, X.; Zhou, J.; Qian, H.; Xu, W.; Qian, J.; Lin, J. miR-374a-5p: A New Target for Diagnosis and Drug Resistance Therapy in Gastric Cancer. Mol. Ther. Nucleic Acids 2019, 18, 320-331. [CrossRef]

120. Li, W.; Gao, Y.Q. MiR-217 is involved in the carcinogenesis of gastric cancer by down-regulating CDH1 expression. Kaohsiung J. Med. Sci. 2018, 34, 377-384. [CrossRef]

121. Lin, L.Y.; Yang, L.; Zeng, Q.; Wang, L.; Chen, M.L.; Zhao, Z.H.; Ye, G.D.; Luo, Q.C.; Lv, P.Y.; Guo, Q.W.; et al. Tumor-originated exosomal lncUEGC1 as a circulating biomarker for early-stage gastric cancer. Mol. Cancer 2018, 17, 84. [CrossRef] 
122. Marengo, A.; Rosso, C.; Bugianesi, E. Liver Cancer: Connections with Obesity, Fatty Liver, and Cirrhosis. Annu. Rev. Med. 2016, 67, 103-117. [CrossRef] [PubMed]

123. Anwanwan, D.; Singh, S.K.; Singh, S.; Saikam, V.; Singh, R. Challenges in liver cancer and possible treatment approaches. Biochim. Biophys. Acta Rev. Cancer 2020, 1873, 188314. [CrossRef]

124. Higashi, T.; Hayashi, H.; Ishimoto, T.; Takeyama, H.; Kaida, T.; Arima, K.; Taki, K.; Sakamoto, K.; Kuroki, H.; Okabe, H.; et al. miR-9-3p plays a tumour-suppressor role by targeting TAZ (WWTR1) in hepatocellular carcinoma cells. Br. J. Cancer 2015, 113, 252-258. [CrossRef] [PubMed]

125. Wang, H.; Hou, L.; Li, A.; Duan, Y.; Gao, H.; Song, X. Expression of serum exosomal microRNA-21 in human hepatocellular carcinoma. Biomed. Res. Int. 2014, 2014, 864894. [CrossRef]

126. Zhang, C.; Yang, X.; Qi, Q.; Gao, Y.; Wei, Q.; Han, S. lncRNA-HEIH in serum and exosomes as a potential biomarker in the HCV-related hepatocellular carcinoma. Cancer Biomark. 2018, 21, 651-659. [CrossRef] [PubMed]

127. Shrestha, A.D.; Neupane, D.; Vedsted, P.; Kallestrup, P. Cervical Cancer Prevalence, Incidence and Mortality in Low and Middle Income Countries: A Systematic Review. Asian Pac. J. Cancer Prev. 2018, 19, 319-324. [CrossRef]

128. Kori, M.; Yalcin Arga, K. Potential biomarkers and therapeutic targets in cervical cancer: Insights from the meta-analysis of transcriptomics data within network biomedicine perspective. PLoS ONE 2018, 13, e0200717. [CrossRef] [PubMed]

129. Zheng, M.; Hou, L.; Ma, Y.; Zhou, L.; Wang, F.; Cheng, B.; Wang, W.; Lu, B.; Liu, P.; Lu, W.; et al. Exosomal let-7d-3p and miR-30d-5p as diagnostic biomarkers for non-invasive screening of cervical cancer and its precursors. Mol. Cancer 2019, 18, 76 [CrossRef]

130. Zhang, J.; Liu, S.C.; Luo, X.H.; Tao, G.X.; Guan, M.; Yuan, H.; Hu, D.K. Exosomal Long Noncoding RNAs are Differentially Expressed in the Cervicovaginal Lavage Samples of Cervical Cancer Patients. J. Clin. Lab. Anal. 2016, 30, 1116-1121. [CrossRef]

131. Elsharkawi, F.; Elsabah, M.; Shabayek, M.; Khaled, H. Urine and Serum Exosomes as Novel Biomarkers in Detection of Bladder Cancer. Asian Pac. J. Cancer Prev. 2019, 20, 2219-2224. [CrossRef] [PubMed]

132. Kalra, H.; Adda, C.G.; Liem, M.; Ang, C.S.; Mechler, A.; Simpson, R.J.; Hulett, M.D.; Mathivanan, S. Comparative proteomics evaluation of plasma exosome isolation techniques and assessment of the stability of exosomes in normal human blood plasma. Proteomics 2013, 13, 3354-3364. [CrossRef]

133. Ghorbanmehr, N.; Gharbi, S.; Korsching, E.; Tavallaei, M.; Einollahi, B.; Mowla, S.J. miR-21-5p, miR-141-3p, and miR-205-5p levels in urine-promising biomarkers for the identification of prostate and bladder cancer. Prostate 2019, 79, 88-95. [CrossRef]

134. Güllü Amuran, G.; Tinay, I.; Filinte, D.; Ilgin, C.; Peker Eyüboğlu, I.; Akkiprik, M. Urinary micro-RNA expressions and protein concentrations may differentiate bladder cancer patients from healthy controls. Int. Urol. Nephrol. 2020, 52, 461-468. [CrossRef]

135. Li, S.; Young, K.H.; Medeiros, L.J. Diffuse large B-cell lymphoma. Pathology 2018, 50, 74-87. [CrossRef]

136. Feng, Y.; Zhong, M.; Zeng, S.; Wang, L.; Liu, P.; Xiao, X.; Liu, Y. Exosome-derived miRNAs as predictive biomarkers for diffuse large B-cell lymphoma chemotherapy resistance. Epigenomics 2019, 11, 35-51. [CrossRef]

137. Cao, D.; Jiang, Y.; Feng, Y.; Jing, C.X.; Xu, J.; Xu, C.G. The Value of Circulating Exsomal miR-451a to Monitor Therapy Response in Diffuse Large B Cell Lymphoma. Sichuan Da Xue Xue Bao Yi Xue Ban 2018, 49, 399-403. [PubMed]

138. Lawrie, C.H.; Gal, S.; Dunlop, H.M.; Pushkaran, B.; Liggins, A.P.; Pulford, K.; Banham, A.H.; Pezzella, F.; Boultwood, J.; Wainscoat, J.S.; et al. Detection of elevated levels of tumour-associated microRNAs in serum of patients with diffuse large B-cell lymphoma. Br. J. Haematol. 2008, 141, 672-675. [CrossRef]

139. Hanada, K.; Okazaki, A.; Hirano, N.; Izumi, Y.; Minami, T.; Ikemoto, J.; Kanemitsu, K.; Hino, F. Effective screening for early diagnosis of pancreatic cancer. Best Pract. Res. Clin. Gastroenterol. 2015, 29, 929-939. [CrossRef]

140. Donahue, T.R.; Dawson, D.W. Leveraging Mechanisms Governing Pancreatic Tumorigenesis To Reduce Pancreatic Cancer Mortality. Trends Endocrinol. Metab. 2016, 27, 770-781. [CrossRef] [PubMed]

141. Melo, S.A.; Luecke, L.B.; Kahlert, C.; Fernandez, A.F.; Gammon, S.T.; Kaye, J.; LeBleu, V.S.; Mittendorf, E.A.; Weitz, J.; Rahbari, N.; et al. Glypican-1 identifies cancer exosomes and detects early pancreatic cancer. Nature 2015, 523, 177-182. [CrossRef]

142. Xu, Y.F.; Hannafon, B.N.; Zhao, Y.D.; Postier, R.G.; Ding, W.Q. Plasma exosome miR-196a and miR-1246 are potential indicators of localized pancreatic cancer. Oncotarget 2017, 8, 77028-77040. [CrossRef]

143. Bray, F.; Ferlay, J.; Soerjomataram, I.; Siegel, R.L.; Torre, L.A.; Jemal, A. Global cancer statistics 2018: GLOBOCAN estimates of incidence and mortality worldwide for 36 cancers in 185 countries. CA Cancer J. Clin. 2018, 68, 394-424. [CrossRef]

144. Torre, L.A.; Trabert, B.; DeSantis, C.E.; Miller, K.D.; Samimi, G.; Runowicz, C.D.; Gaudet, M.M.; Jemal, A.; Siegel, R.L. Ovarian cancer statistics, 2018. CA Cancer J. Clin. 2018, 68, 284-296. [CrossRef] [PubMed]

145. Srivastava, A.; Moxley, K.; Ruskin, R.; Dhanasekaran, D.N.; Zhao, Y.D.; Ramesh, R. A Non-invasive Liquid Biopsy Screening of Urine-Derived Exosomes for miRNAs as Biomarkers in Endometrial Cancer Patients. AAPS J. 2018, 20, 82. [CrossRef] [PubMed]

146. Gao, Y.; Dai, M.; Liu, H.; He, W.; Lin, S.; Yuan, T.; Chen, H.; Dai, S. Diagnostic value of circulating miR-21: An update meta-analysis in various cancers and validation in endometrial cancer. Oncotarget 2016, 7, 68894-68908. [CrossRef]

147. Krishn, S.R.; Salem, I.; Quaglia, F.; Naranjo, N.M.; Agarwal, E.; Liu, Q.; Sarker, S.; Kopenhaver, J.; McCue, P.A.; Weinreb, P.H.; et al. The $\alpha \mathrm{v} \beta 6$ integrin in cancer cell-derived small extracellular vesicles enhances angiogenesis. J. Extracell. Vesicles 2020, 9, 1763594. [CrossRef] [PubMed]

148. Maia, J.; Caja, S.; Strano Moraes, M.C.; Couto, N.; Costa-Silva, B. Exosome-Based Cell-Cell Communication in the Tumor Microenvironment. Front. Cell Dev. Biol. 2018, 6, 18. [CrossRef] [PubMed] 
149. Wang, T.; Diaz, A.J.; Yen, Y. The role of peroxiredoxin II in chemoresistance of breast cancer cells. Breast Cancer 2014, 6, 73-80. [CrossRef]

150. Mascanfroni, I.D.; Yeste, A.; Vieira, S.M.; Burns, E.J.; Patel, B.; Sloma, I.; Wu, Y.; Mayo, L.; Ben-Hamo, R.; Efroni, S.; et al. IL-27 acts on DCs to suppress the T cell response and autoimmunity by inducing expression of the immunoregulatory molecule CD39. Nat. Immunol. 2013, 14, 1054-1063. [CrossRef]

151. Bruchhage, K.L.; Heinrichs, S.; Wollenberg, B.; Pries, R. IL-10 in the microenvironment of HNSCC inhibits the CpG ODN induced IFN- $\alpha$ secretion of pDCs. Oncol. Lett. 2018, 15, 3985-3990. [CrossRef] [PubMed]

152. Zhang, Y.; Zhang, Y.; Yin, Y.; Li, S. Detection of circulating exosomal miR-17-5p serves as a novel non-invasive diagnostic marker for non-small cell lung cancer patients. Pathol. Res. Pract. 2019, 215, 152466. [CrossRef]

153. Xin, H.; Katakowski, M.; Wang, F.; Qian, J.Y.; Liu, X.S.; Ali, M.M.; Buller, B.; Zhang, Z.G.; Chopp, M. MicroRNA cluster miR-17-92 Cluster in Exosomes Enhance Neuroplasticity and Functional Recovery After Stroke in Rats. Stroke 2017, 48, 747-753. [CrossRef] [PubMed]

154. Yoshioka, Y.; Kosaka, N.; Konishi, Y.; Ohta, H.; Okamoto, H.; Sonoda, H.; Nonaka, R.; Yamamoto, H.; Ishii, H.; Mori, M.; et al. Ultra-sensitive liquid biopsy of circulating extracellular vesicles using ExoScreen. Nat. Commun. 2014, 5, 3591. [CrossRef]

155. Li, M.; Zhou, Y.; Xia, T.; Zhou, X.; Huang, Z.; Zhang, H.; Zhu, W.; Ding, Q.; Wang, S. Circulating microRNAs from the miR106a-363 cluster on chromosome $X$ as novel diagnostic biomarkers for breast cancer. Breast Cancer Res. Treat. 2018, 170, 257-270. [CrossRef] [PubMed]

156. Liang, Y.; Song, X.; Li, Y.; Chen, B.; Zhao, W.; Wang, L.; Zhang, H.; Liu, Y.; Han, D.; Zhang, N.; et al. LncRNA BCRT1 promotes breast cancer progression by targeting miR-1303/PTBP3 axis. Mol. Cancer 2020, 19, 85. [CrossRef] 